\title{
MARJAMURTO, AN INTERSTADIAL SITE IN A TILL-COVERED ESKER AREA OF CENTRAL OSTROBOTHNIA, WESTERN FINLAND
}

\author{
HANNU PELTONIEMI, BRITA ERIKSSON, TUULIKKI GRÖNLUND and \\ MATTI SAARNISTO
}

\begin{abstract}
PELTONIEMI, HANNU, ERIKSSON, BRITA, GRÖNLUND, TUULIKKI and SAARNISTO, MATTI, 1989: Marjamurto, an interstadial site in a till covered esker area of central Ostrobothnia, western Finland. Bull. Geol. Soc. Finland 61, Part 2, 209-237.

Till-covered glaciofluvial deposits, presumably eskers, are common in Central Ostrobothnia (Pohjanmaa) within a zone more than $50 \mathrm{~km}$ broad, in which no exposed eskers are present. The areal distribution, morphology and stratigraphy of these eskers are described with particular reference to the organic deposits found in many gravel pits within this zone. Some of the organic sediments, such as the Ollala site in Haapavesi, have been correlated with the Eemian Stage, whereas some sites such as Oulainen have been correlated with the Early Weichselian Brørup Interstadial. The Marjamurto site in Haapavesi, described here, probably belongs to the same esker chain as that at Oulainen. It is a freshwater sequence deposited in a kettle hole, and was later buried by littoral sands and till. The palaeovegetation represents an interstadial type of pine-dominated forest. On the basis of its lithostratigraphy and biostratigraphy, the Marjamurto sequence is correlated with that at Oulainen. A preliminary TL date for Marjamurto of 107 ka supports this correlation. The possibility of correlating the 'forested' interstadials of Ostrobothnia with the Early Weichselian Odderade Interstadial is also considered.

The Early Weichselian deposits in Ostrobothnia are overlain by only one till unit, as indeed also are the deposits correlated with the Eemian Stage. This suggests that the Weichselian ice spread to southern Finland only once. Thus the tillcovered eskers of Ostrobothnia must themselves date from the late Saalian Stage.
\end{abstract}

Key words: stratigraphy, till, eskers, organic residues, pollen diagrams, diatom flora, interstadial environment, Weichselian, Marjamurto, Haapavesi, Finland.

Hannu Peltoniemi: Tie- ja vesirakennuslaitos, SF-84101 Ylivieska, Finland. Brita Eriksson, Tuulikki Grönlund and Matti Saarnisto: Geological Survey of Finland, SF-02150 Espoo, Finland.

\section{Introduction}

A zone of glaciofluvial deposits underlying till occurs in the Pyhäjoki and Kalajoki valley area in Central Ostrobothnia, western Finland. The south-western boundary of this zone extends from Pyhäjärvi through Haapajärvi, Ylivieska and Alavieska to Pyhäjoki (Figs. 1 and 2). The zone apparently borders the Pattijoki-Vihanti-
Piippola-Pyhäntä esker chain in the north-east, although no buried glaciofluvial sediments have been found in the immediate vicinity. Esker deposits overlain by till have been reported from about fifty localities in this zone (Fig. 2), about twenty of which were identified during the course of a Geological Survey of Finland project undertaken to assess the sand and gravel resources (c.f. Iisalo 1973; Iisalo et al. 1974; Niemelä 1979). The 


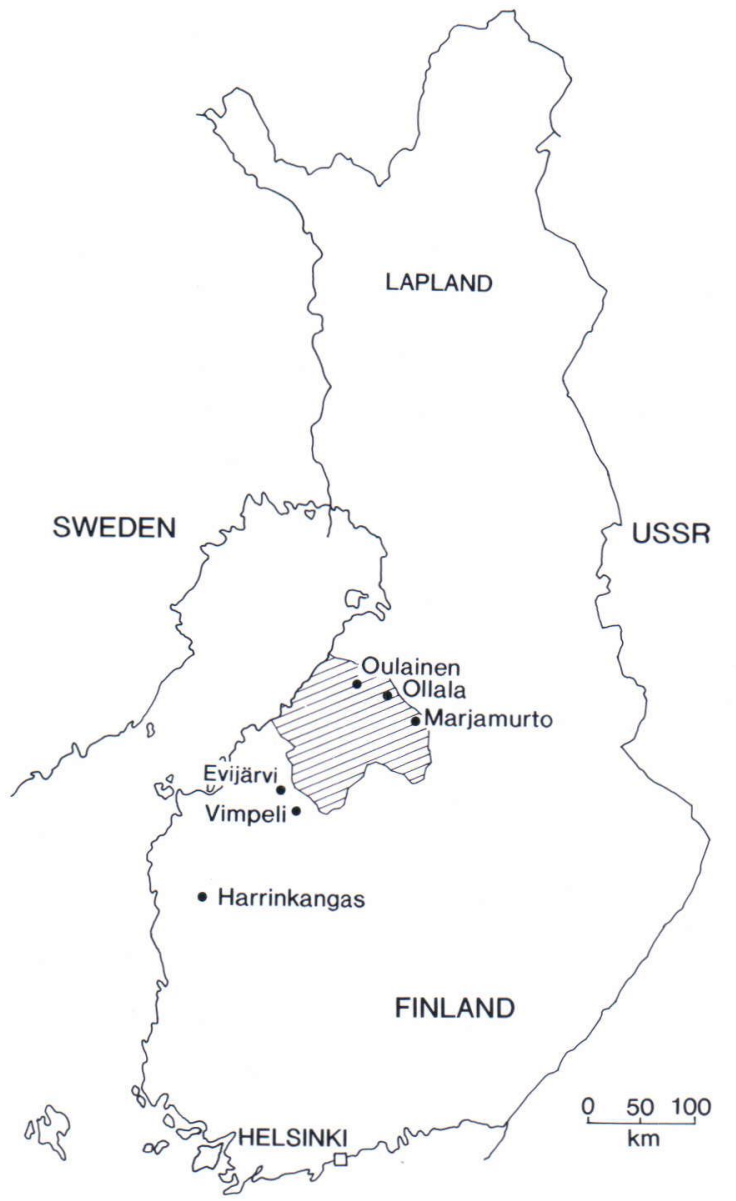

Fig. 1. Location map showing the study area in Central Ostrobothnia (shaded) together with some locations mentioned in the text.

remainder were discovered during mapping by the Department of Public Roads and Waterways (TVL).

In addition, many sites in Ostrobothnia are known to include organic material such as wood, peat, gyttja or organic silt sediments beneath till, many of which occur in gravel pits in eskers. During the mapping of buried gravel and sand deposits in Central Ostrobothnia one of the authors (H.P.), discovered organic sediment at the Marjamurto site in Haapavesi. This locality is close to those at Oulainen and Ollala, deposits at which have been correlated with the Early
Weichselian Substage Brørup Interstadial and the Eemian Stage respectively (e.g. Forsström 1982; Forsström et al. 1987).

The Marjamurto site was investigated and sampled by the authors (H.P. and M.S.) in December 1987 and August 1988. The present paper describes its litho-, pollen and diatom stratigraphies, and discusses the palaeoenvironments which these represent. It concludes with a proposal for correlating the sequence with the regional Quaternary stratigraphy of Ostrobothnia and NW Europe. First, however, the distribution and characteristics of till-covered glaciofluvial sediments of Central Ostrobothnia are described.

\section{Till-covered eskers in Central Ostrobothnia}

A typical feature of buried eskers is the flatness of their topography, for in many cases they scarcely rise above the level surface of their surroundings. An example of such a buried esker is the Pylväsperä accumulation at Ylivieska (Fig. 2, A). Since these eskers must have been created during an earlier glacial phase and then buried by a later ice advance, their preservation intact is dependent on a sheltered location, such as against a bedrock outcrop. An example of this type of preservation is the Tähtäjänjoki chain in Pyhäjoki (Fig. 2, B).

It appears that only the larger parts of the old eskers have survived the process of subsequent glacial erosion sufficiently well to remain visible as convex landforms where the protection of a bedrock outcrop is lacking. In this case the resulting till-covered ridges can still be of substantial size. Some have the superficial appearance of drumlins, and can vary in height from a few to over $10 \mathrm{~m}$. Their slopes are usually fairly gentle and the 'hog's-back' shape typical of normal eskers, is absent. Three such ridge-shaped buried eskers are found to the east and north-east of Haapavesi town, a typical example being Nevalanmäki at Kytökylä (Fig. 2, C). Comparable forms, rising well above the surrounding terrain, 


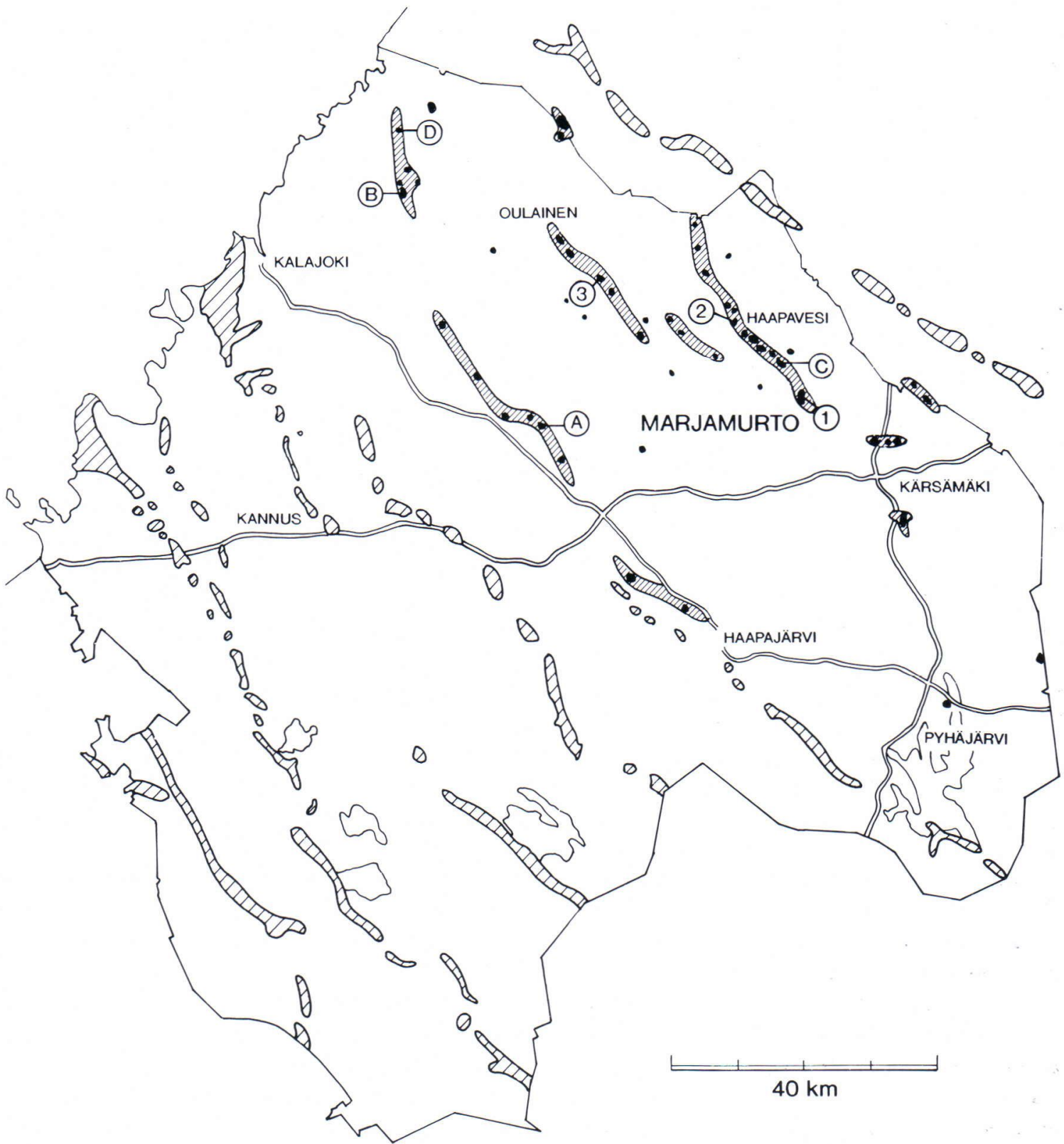

Fig. 2. Map depicting the buried eskers (black), their suggested continuation (dark shaded) and late Weichselian eskers (shaded) of Central Ostrobothnia. The locations of the Marjamurto (1), Haapavesi, Ollala (2) and Oulainen (3) localities are also indicated, as the esker formations $\mathrm{A}, \mathrm{B}, \mathrm{C}, \mathrm{D}$ described in the text.

are also present at Pyhäjoki, Oulainen and Kärsämäki, whereas accumulations in the Kalajoki valley are usually flattened in forms.

The overlying till cover on the flattened eskers, situated on low-lying ground, is usually continu- ous, but variable in thickness, ranging from a half to several metres. Frequently a till bed of this type has a level upper surface, but an undulating basal contact with the underlying esker sediments. Conversely, on a convex landform the till 
unit will tend to be thicker on the slopes and thinner on the summit, the mean till depth being $1.5-2 \mathrm{~m}$. Occasionally no till is present on the crest, as a result of subsequent washing by the sea during postglacial emergence.

Where buried eskers are located on the lee-side of a bedrock outcrop virtually the opposite situation occurs, i.e. the till is thickest on the crest and immediately adjacent to the outcrop, but it becomes progressively thinner in the direction of glacial flow, and particularly in the direction transverse to the esker ridge orientation itself. This is the case at Kötinkangas, in Pyhäjoki commune (Fig. 2, D), where the till depth at the centre of the esker ridge is about $1.5 \mathrm{~m}$, but thins rapidly from the centre of the crest to the margins so that it is only c. $20 \mathrm{~cm} \mathrm{20-30} \mathrm{metres} \mathrm{away.} \mathrm{Indeed}$ the till may even be absent entirely from the extreme edges of the ridge, although the excavations do not normally extend to the margins. Till overlying the esker has not at these margins generally been affected as much by wave washing as at the highest point on the ridge crest.

In general there is a very sharp unconformity between the till and the underlying glaciofluvial gravel or sand. This contact surface is often like a slip plane, with the material below compressed, deformed and folded by the overlying ice sheet. The sediment also includes small-scale fractures. These structures, and more particularly the orientation of the drag folds occurring immediately beneath the sand/till unconformity can in places permit direction of glacial movement to be determined fairly accurately. The till normally has a silty matrix, which is brownish grey in colour or, less commonly, dark grey in its lower parts. Where the ice flowed over glaciofluvial material for some distance, the till is often more sandy, especially in the lower parts. Interlayers or lenses of sand are found in such tills in places on the distal sides of buried eskers. Such features can potentially create difficulties where till stratigraphy is based on temporary shallow test pit excavations. The glaciofluvial sand at Hietakangas in Haapavesi town is overlain by clay locally called »hill clay» (mäkisavi), which in turn is covered by a thin layer of silty till, modified by strong littoral erosion. This clay lacks clasts at the base in places, but becomes more stony upwards, to form clay-rich diamicton that has been referred to as »hill clay till» in field descriptions.

This zone of buried eskers contains no examples of dead ice hummocky moraines nor does any of the till covering the concealed eskers include evidence of washed ablation till. Both the morainic landforms orientated parallel to the direction of glacial flow and the material of which they are composed, indicate that the uppermost till in this zone of buried eskers was laid down by actively moving ice (cf. Punkari 1979).

Some of the till-covered glaciofluvial formations are isolated from the esker chains and cannot, at present, be assigned to any particular network. Conversely, a number of the formations can be assigned to an individual esker chain and sometimes can be traced for a considerable distance. Nevertheless, at present the course of the ancient esker chains cannot be reconstructed with any accuracy, although it appears that their general orientation seems to be very similar to that of the more recent unburied eskers in the region. An esker chain that has survived glacial erosion particularly well is that in Haapavesi town. This is aligned from close to the Vihanti commune border and runs south-west of Pirnesjärvi and Apajajärvi towards Ollala and to Sulkakylä. In the Sulkakylä-Tötteröperä area, it may then join another chain which runs towards Oulainen, closely following the Pyhäjoki valley. This formation has again been detected at a number of points. In any case, it is continuous from Mustikkamäki, at Tötteröperä, through Nevalanmäki, near Kytökylä to Savaloja, where it appears to end. Possible continuations of this chain nevertheless exist at Porkkala and Haudanjoenperä in Kärsämäki. Correspondingly, the formations discovered in the Kalajoki valley may virtually all belong to a single esker chain, which roughly follows the course of the present valley, although there are far fewer observations of bu- 
ried eskers here than in the Pyhäjoki valley. It is nevertheless probable that there are still buried esker formations in the region that have yet to be discovered. Therefore the knowledge of the course of the ancient esker chains in the Pyhäjoki and Kalajoki valleys will improve in the future.

\section{The Marjamurto site}

\section{Lithostratigraphy and sampling sites}

The Marjamurto site is located about $10 \mathrm{~km}$ east of Haapavesi town. It occurs in the same buried glaciofluvial system in which the Oulainen site, some $30 \mathrm{~km} \mathrm{WNW}$ is evidently also situated. The original altitude of the ground surface was approx. $95 \mathrm{~m}$ a.s.l., but the top of the hill has been removed during excavation. The extent of the gravel pit in summer 1989 was approximately 100 x 150 m (Fig. 3).

An section excavated in the centre of the gravel pit (Site A, Fig. 4) revealed the following sequence:

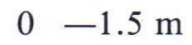

Reddish-brown compact till, of which only the lower part, approximately half a metre, remains, rests on sediments beneath with a marked unconformity
Marjamurto

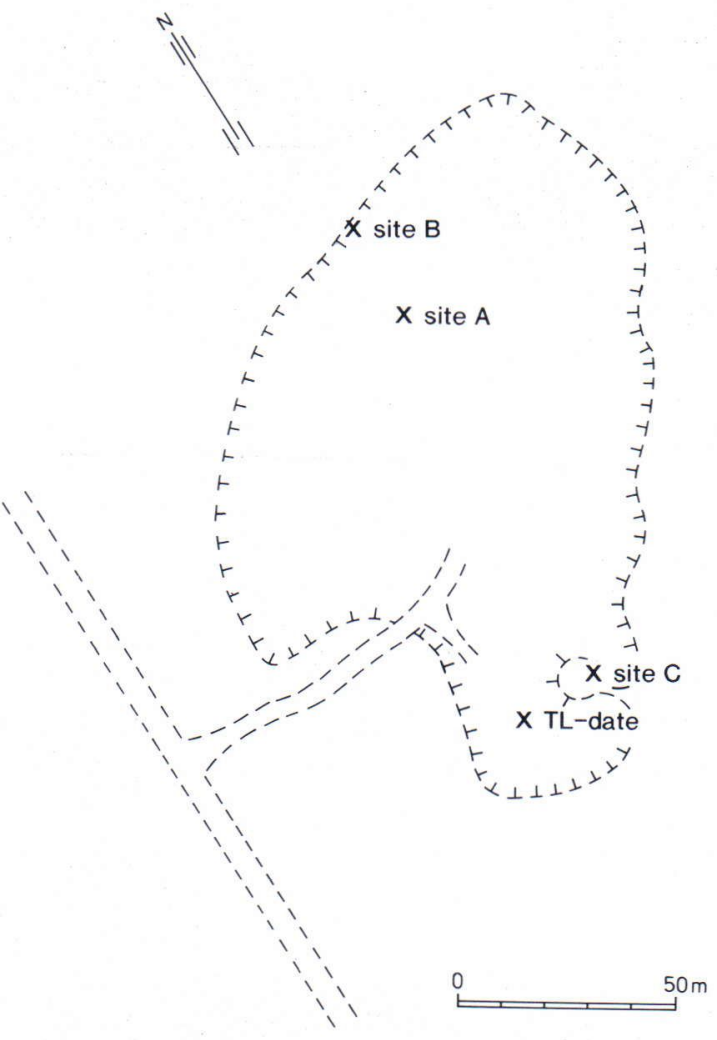

Fig. 3. Sketch plan of the Marjamurto pit and sampling sites A, B and C. (Topographic map sheet 3411 02.)
Fig. 4. Photograph showing the upper part of the organic desposit underlying sand (and till). Site A at Marjamurto.

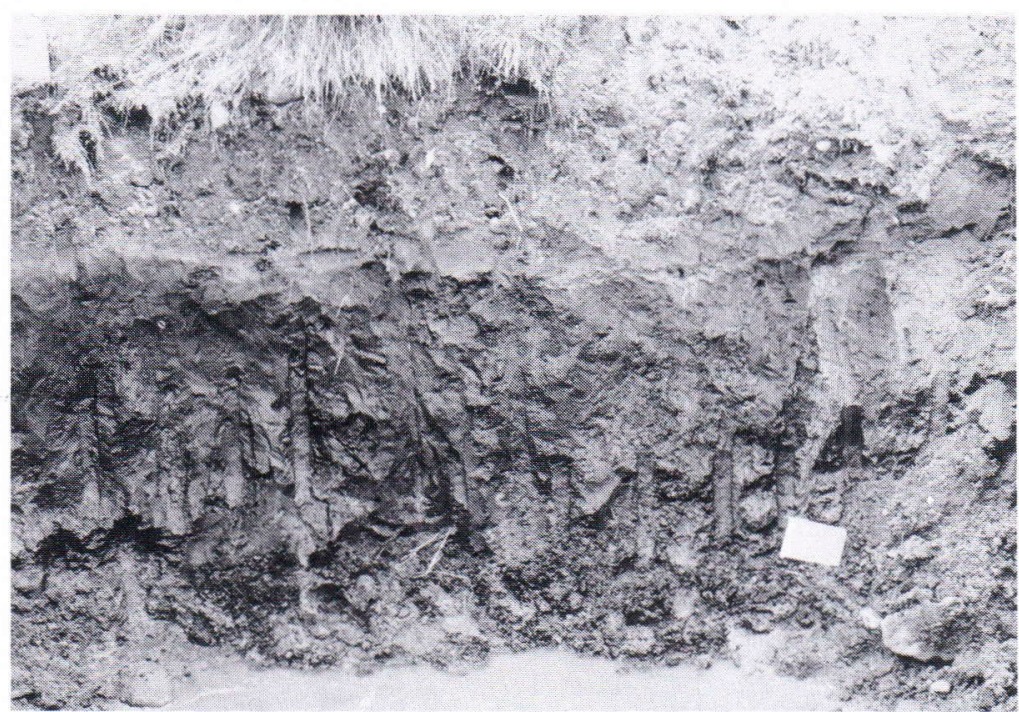




\section{$1.5-2.0 \mathrm{~m} \quad$ Horizontally bedded sand with a gradual transition at the lower contact}

2.0-4.2 m Gyttja fine silt with a loss-onignition of about $5 \%$, containing many splinters of wood in the upper $20 \mathrm{~cm}$ and grading in colour from greenish at the base through brownish-grey to brown

$4.2-5.5 \mathrm{~m}$ Grey fine sand

$5.5-6.0 \mathrm{~m}$ Laminated silt/fine sand

6.0- Sand, base not seen

A consistent sequence in which sand is overlain by till is present in sections throughout the gravel pit. However, in November 1987 a thin gyttja silt horizon of a maximum thickness of 0.5 $\mathrm{m}$ was seen at the north-western corner (Site B). Two samples were taken from this site for microfossil analysis, the upper consisting of gyttja silt, containing wood fragments, and the lower of sulphide-bearing silt.

A channel some 5-7 m wide and 2-3 m deep, eroded into coarse sorted sediment and infilled with sand, clay and silt containing organic material, was found at many points below till on the southern side of the pit. Site $C$ represents the channel fill, in which the organic material is present in narrow bands and discrete clasts of clay within the sand (Figs. 5 and 6). Eleven samples were taken from this site, of which numbers 1 and 2 were from a clay horizon in the upper part of the channel, numbers 3-5 were from the gyttja silt with streaks of organic material and numbers $6-10$ were from an isolated clay clast $40 \mathrm{~cm}$ in diameter from the base of the channel. The latter included graded bedding of silt and organic material enabling its original direction of deposition to be determined. Sample 11 was second isolated clay clast from the sand at the base of the channel.

Samples were collected from the sand at both Site A and Site C for thermoluminescence dating, in addition to which a further thermoluminescence sample was taken from the same channel fill material near Site C (Fig. 3). These

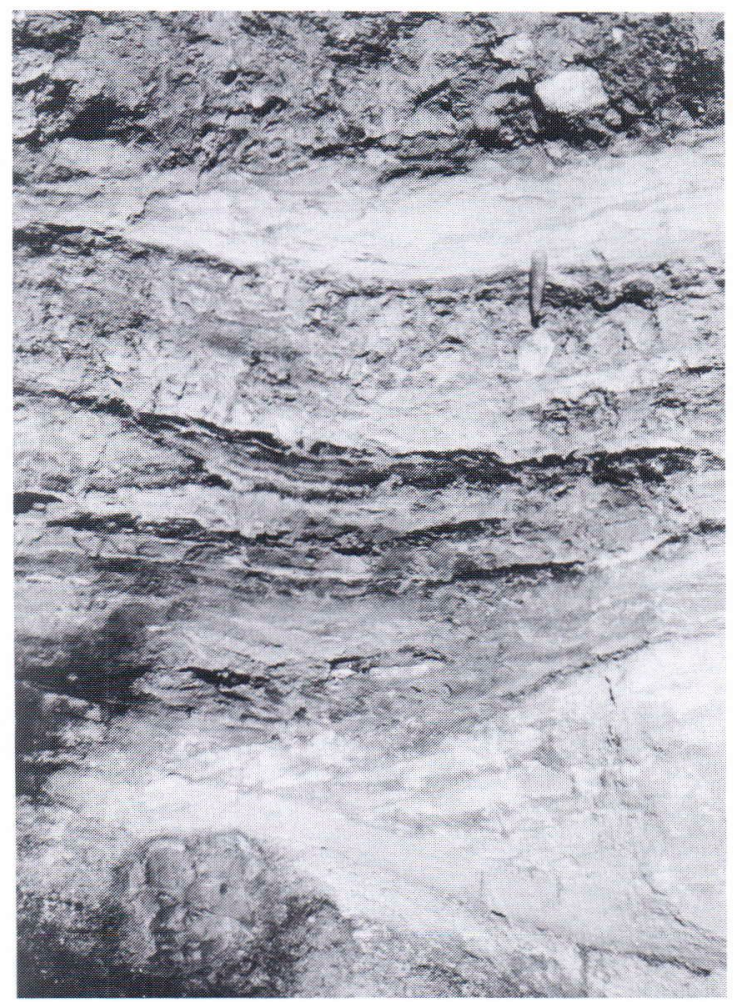

Fig. 5. Photograph showing the channel-fill deposits underlying till at Site C Marjamurto.

samples represent the upper part of the channel fill immediately below the till.

The lithostratigraphy of Site A from 4.2$1.5 \mathrm{~m}$ is interpreted as indicating water of gradually diminishing depth, perhaps a bay of a lake, resulting from progressive infilling, or a fluvial environment. The horizontally bedded sand between $2.0-1.5 \mathrm{~m}$ is most likely of littoral origin. The organic silt at $4.2-2.0 \mathrm{~m}$ is evidently in situ, whereas the organic sediments at Sites B and C, on the other hand, are undoubtedly reworked glaciofluvial channel fill material.

\section{The Marjamurto Till}

The Marjamurto Till is fairly densely packed, massive and reddish-brown in colour, with pockets of blue-grey till visible in places in the lower 


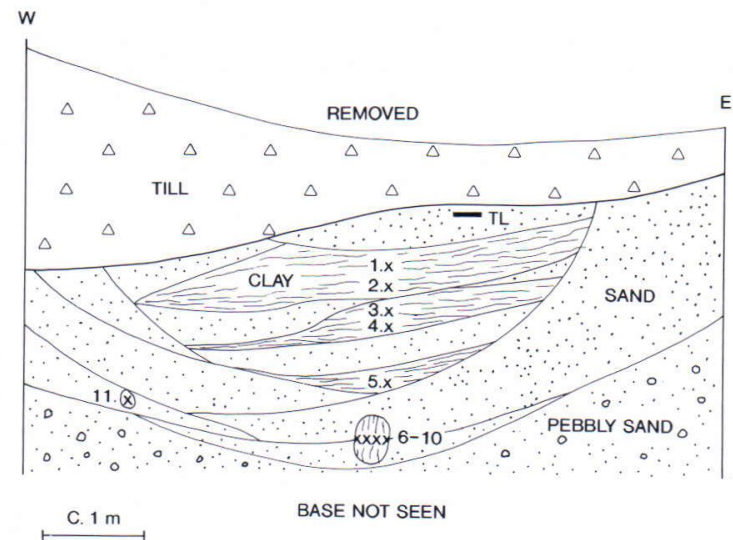

Fig. 6. Sketch showing the channel-fill deposits underlying till at site C Marjamurto. The sample localities $1-11$ are indicated together with the locality for the TL-sample.

Table 1. Lithology of clasts from the Marjamurto Till

\begin{tabular}{lcc}
\hline Rock type & Upper $\%$ & Lower $\%$ \\
\hline Granite & 25 & 29 \\
Granodiorite & 21 & 16 \\
Gabbro-diorite & 1 & 5 \\
Mica schist-gneiss & 24 & 25 \\
Amphibolite & 11 & 10 \\
Quartz-feldspar schist & 18 & 15 \\
\hline Total pebbles & 100 & 100 \\
\hline
\end{tabular}

\section{Pollen stratigraphy}

part of the unit near Site B. The matrix is siltrich, with a relatively high clay content of $13 \%$. Two fabric analyses show a north - south orientation, a common direction for the youngest glacial flow in the Central Ostrobothnia region (see Nenonen 1986). Similarly two pebble counts from the till, one from the reddish-brown upper part and the other from the bluish-grey lower part suggest that the two subunits do not differ lithologically (Table 1). This confirms that only one till unit is present within which a colour change, presumably resulting from oxidization is present. This interpretation is supported by the trace metal content of the fines in the reddish-brown subunit, which is about three times greater than that of the blue-grey subunit.

Granitoids account for approximately $45 \%$ of the pebbles in the till. This is expected since the

\section{Methods}

bedrock consists largely of these rocks within a radius of about $20 \mathrm{~km}$ to the north and west of Marjamurto (Salli 1958). It is curious, however, that gabbros and diorites account for only a few percent, since the Marjamurto site itself is located on a gabbro-diorite massif. On the other hand, the various schists are apparently over-represented in the pebble counts in relation to their distribution in the bedrock. This suggests that the map may be somewhat inaccurate in this respect. The most interesting feature, as far as the schists are concerned, is the high proportion of quartzfeldspar schists. This supports the conclusion obtained from the till fabric analysis that the ice flowed from a virtually northerly direction, since the felsic volcanites are found in abundance in Vihanti, the commune immediately north of Haapavesi. There is also another extensive schist area, about $20 \mathrm{~km}$ west of Marjamurto, from which the schist clasts in the till could have been derived if the direction of glacial transport had been from the WNW or west.

The samples for pollen analysis were treated with hydrogen fluoride (cold method) and then boiled in $10 \% \mathrm{KOH}$. The slides were mounted in glycerine, and a total of 300 arboreal pollen grains per slide were counted. The slides were also scanned for pollen taxa occurring in very small numbers. The sums from which the percentages of the pollen and spore types were calculated are indicated on the diagrams (Figs. 7-9).

\section{Site A}

The gyttja silt (2.0-4.2 m) and sand (4.2-4.6 $\mathrm{m}$ and $5.5 \mathrm{~m}$ ) were sampled at $5-10 \mathrm{~cm}$ intervals. The relative frequencies of the arboreal pollen types were markedly high throughout, except in the lowest part of the profile, $4.3-5.5 \mathrm{~m}$, and the grains were in good condition other than in 


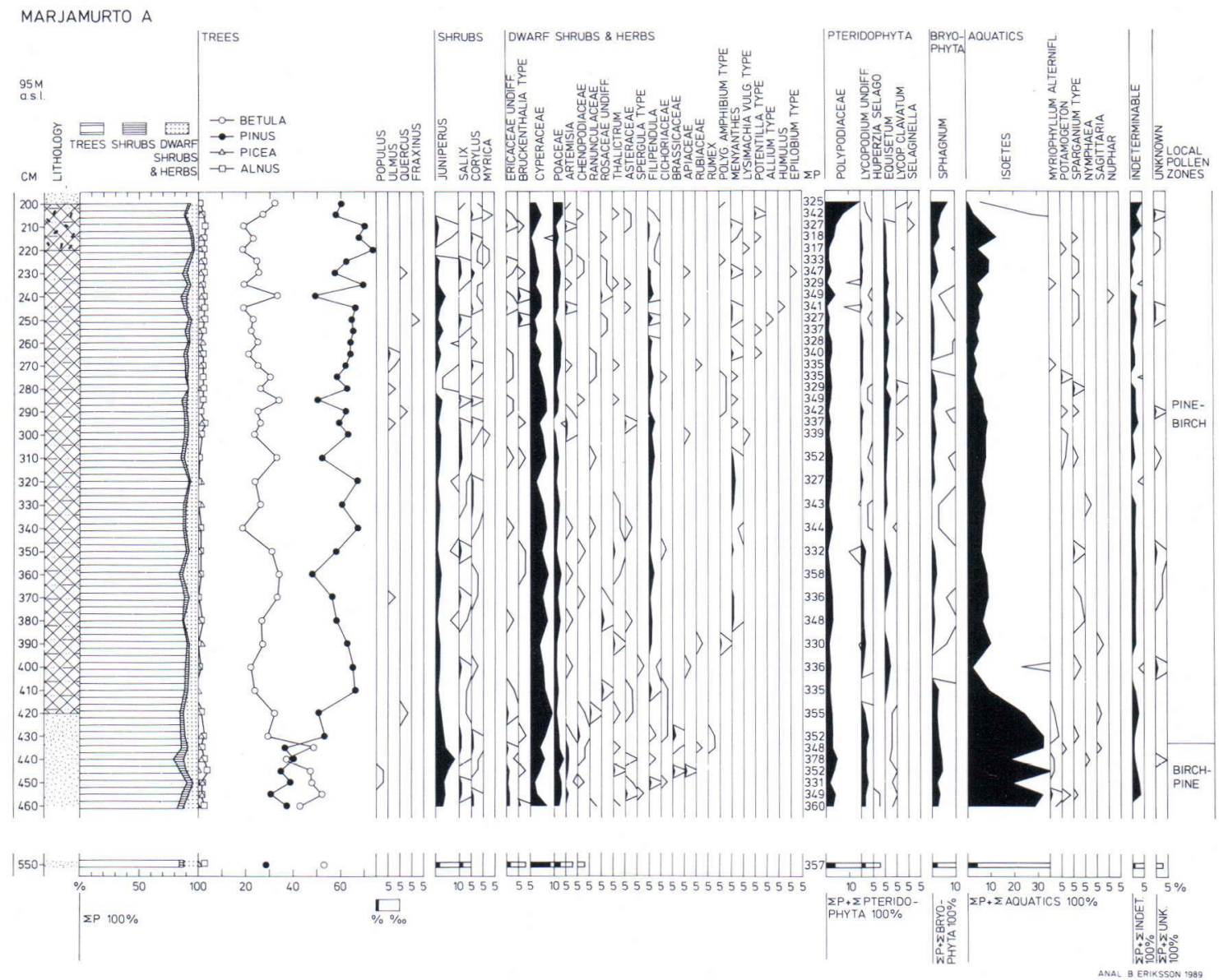

Fig. 7. Pollen diagram for Site A at Marjamurto.

the uppermost sample. An effort was made to distinguish any Betula nana present among the Betula pollen on the basis of both size and the projection of the pore, but apparently only a few grains in each sample represented this type. Two local pollen assemblage zones were distinguished on the relative pollen diagram (Fig. 7).

Birch-pine pollen zone. Birch pollen is dominant to some extent in most of the samples, $37-53 \%$, with pine reaching values of $29-39 \%$. Isolated spruce grains are present, and alder to the extent of $2-3 \%$. Arboreal pollen makes up about $80-90 \%$ of total pollen, while the shrubs account for $3-8 \%$, consisting mainly of Juniperus. Dwarf shrub and herb pollen amount to about $10 \%$. Continuous curves are obtained for Ericaceae and Artemisia, and large amounts of Isoëtes pollen are present in this zone and at the beginning of the next, reaching a maximum of about $36 \%$. The pollen spectrum for the lowermost sample, from $5.5 \mathrm{~m}$, resembles the above except that the juniper values are lower and there is $<4 \%$ Isoëtes pollen.

Pine-birch pollen zone. The values for pine increase to over $50 \%$ at the beginning of the zone and pine becomes the dominant pollen type from this point onwards, reaching a maximum of $73 \%$. Arboreal pollen as a proportion of total pollen is $85-90 \%$, the figure being highest in the upper part of the profile. The Juniperus curve falls 
to a low level at the beginning of the zone and remains there throughout, and the Ericaceae and Artemisia curves are sporadic. The amounts of Isoëtes pollen decline sharply at the boundary between sand and gyttja silt, after which they become established at 5-10\%.

\section{Vegetational interpretation}

The area was evidently covered by closed forests of birch and pine at the time when sand was being deposited in the basin (levels 5.50$4.35 \mathrm{~m}$ ), with juniper growing in sunny places and possibly a little alder at damper sites. By the time the upper part of the sand and the whole two metres of gyttja silt was being deposited the regional vegetation consisted predominantly of pine forests with a fair proportion of birch and occasional alders present on the shores. The local vegetation also included Filipendula and Menyanthes, which thrived in the more moist environments, as well as juniper, sedges and grasses. The presence of pollen of the Bruckenthalia type throughout the profile in amounts ranging from $0.3 \%$ to $2.0 \%$ indicates that some Bruckenthalia species must have occurred in the relatively sparse dwarf shrub vegetation. Large amounts of Isoëtes evidently grew in the water of the basin, diminishing as deposition of the gyttja silt horizon began. Most of the most common aquatic plants were present in the shallow water close to the shore.

\section{Site $B$}

Although the upper sample taken at this site was from the gyttja silt and the lower one from the sulphide clay, their pollen spectra are very similar. Both contain $>60 \%$ Betula, $<23 \% \mathrm{Pi}$ nus and $85-87 \%$ arboreal pollen as a percentage of total pollen. The pollen flora in both sediments reflects a birch-dominated forest in a cool climatic zone.
Site $C$

Analyses were made of 11 samples from the channel fill material, of which pollen spectra are presented for numbers $1-10$ in Figures 8 and 9 . Sample 1 was devoid of pollen, but the others all contained relatively high pollen frequencies, although the grains themselves were badly worn. Samples 2-10 all had some 3-8\% Betula nana type pollen ( $\%$ of total pollen), although these are not listed separately in the diagrams as the uncertainty attached to their recognition was further heightened by the poor condition of the grains. Individual pollen grains of pre-Quaternary conifers were found in practically all the samples.

Arboreal pollen accounts for $>70 \%$ of total pollen in samples $2-5$ (Fig. 8), and dwarf shrubs and herbs for $18-24 \%$. The proportions of pine and birch pollen vary around $35 \%$, except in sample 2, where pine forms a clear majority with $55 \%$ against $25 \%$ birch. Very little Picea, Alnus or Corylus pollen are present. The non-arboreal pollen represents mainly sedges and grasses, and there are few Sphagnum spores. In addition to the Sparganium type (= Sparganium / Typha angustifolia), some pollen of Nuphar, Nymphaea and Sagittaria are also present.

The pollen spectra for samples 6-10 (Fig. 9) are very similar to those for nos. 3-5. The proportions of pine and birch pollen vary between 30 and $45 \%$, and alder reaches a maximum of $2.9 \%$ and spruce of $1 \%$. Sample 10 also contains a Carpinus grain and a spore of Osmunda.

The redeposited pollen flora of the channelfill sediments is thus highly comparable to the flora of the clay clast represented by samples $6-10$, both indicating a mixed pine-birch forest typical of cool climatic conditions, with local communities of grasses and sedges. The clay clast may indeed have broken away from the same deposit from which the pollen of the channel-fill sediments was derived.

The pollen contained in the second isolated clay clast recovered from the channel fill material at the lower edge of the channel (sample 11) 
MARJAMURTO C 1

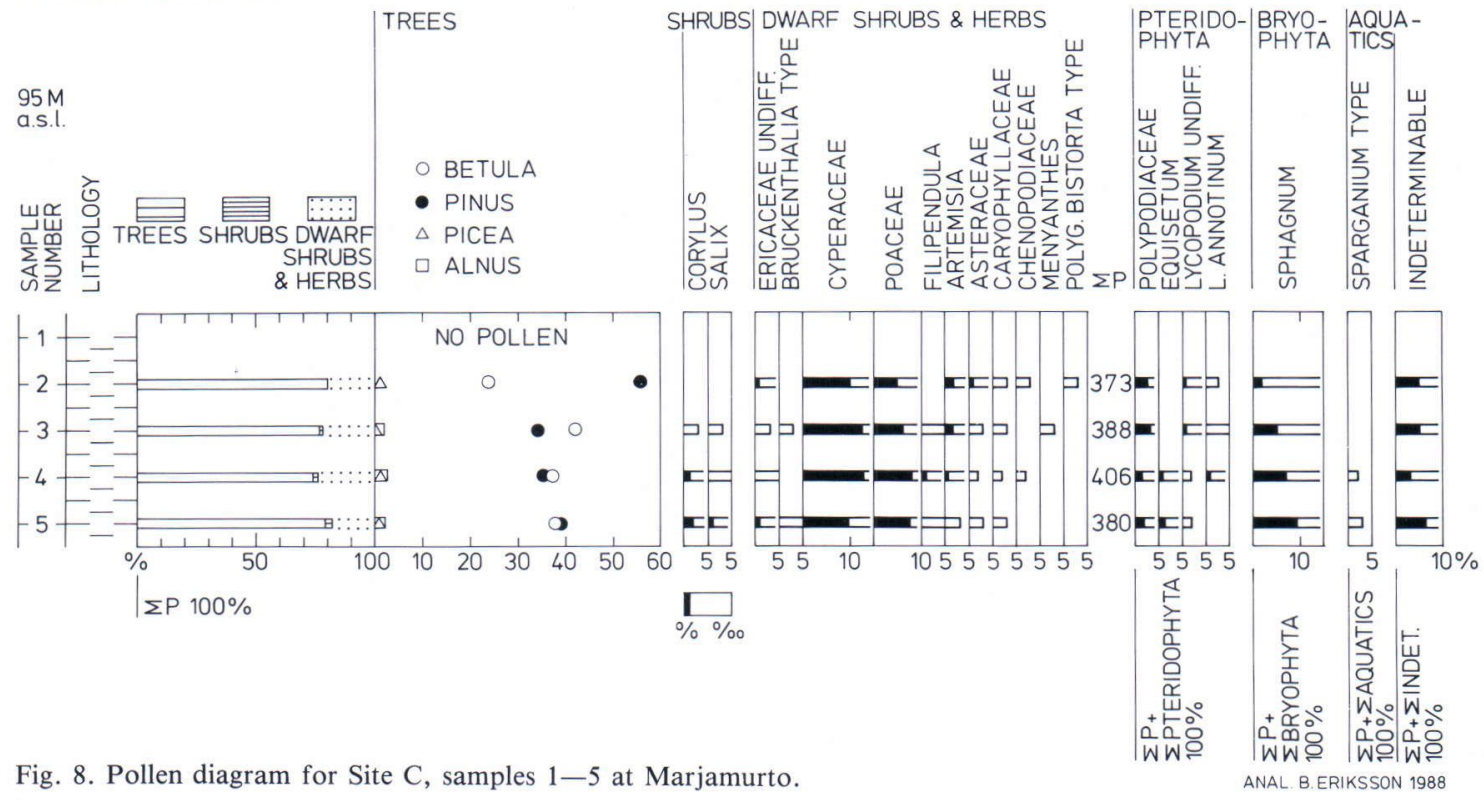

MARJAMURTO C2

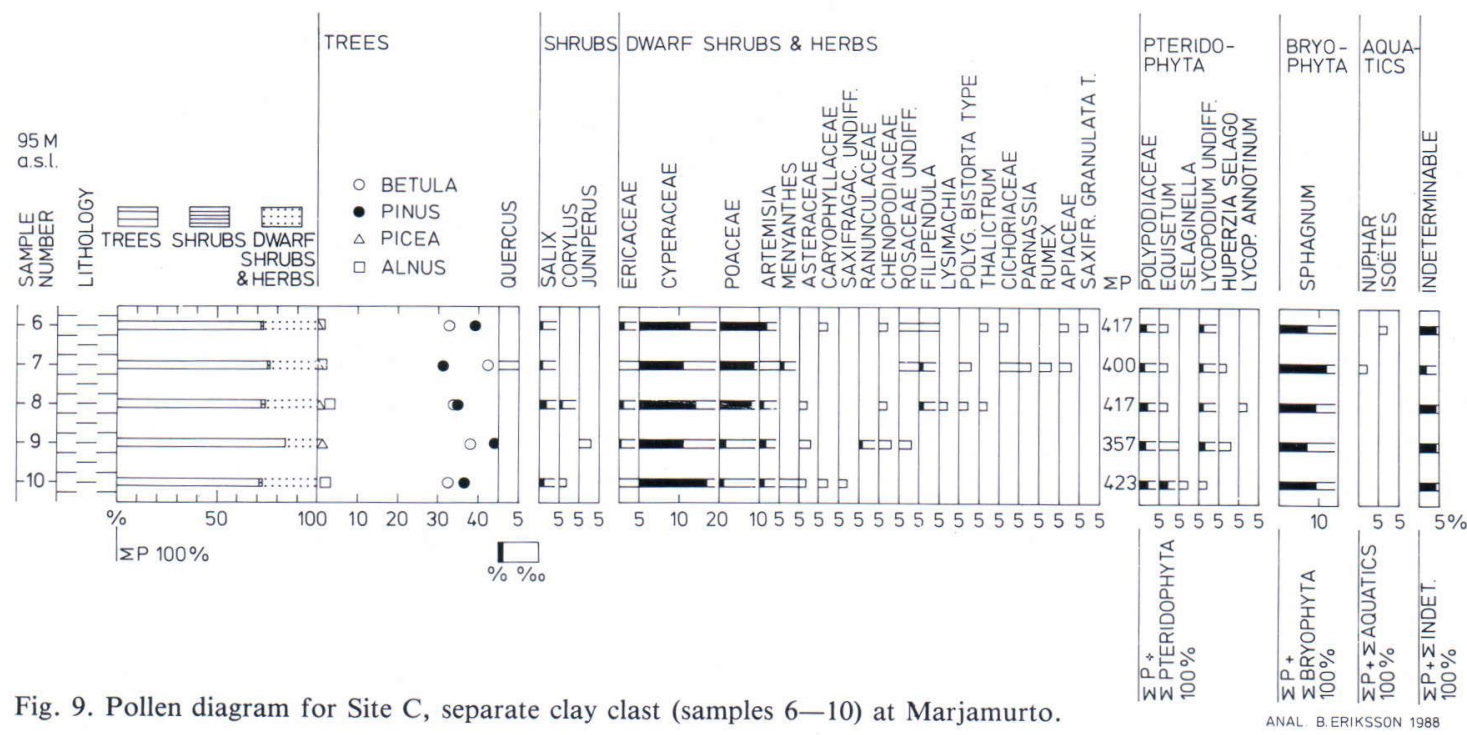

was extremely worn. Thus only 100 arboreal pollen grains were counted, making up $54 \%$ of a pollen sum of 185 , with the dwarf shrubs and herbs accounting for about $42 \%$. Birch pollen amounted to $51 \%$ and alder $3 \%$. This flora sug- gests that the clay had been deposited under subarctic conditions involving an open birch forest with some Salix and Juniperus and a lower vegetation dominated by grasses.

Samples from the upper and lower tills at Site 
MARJAMURTO A

Diatoms

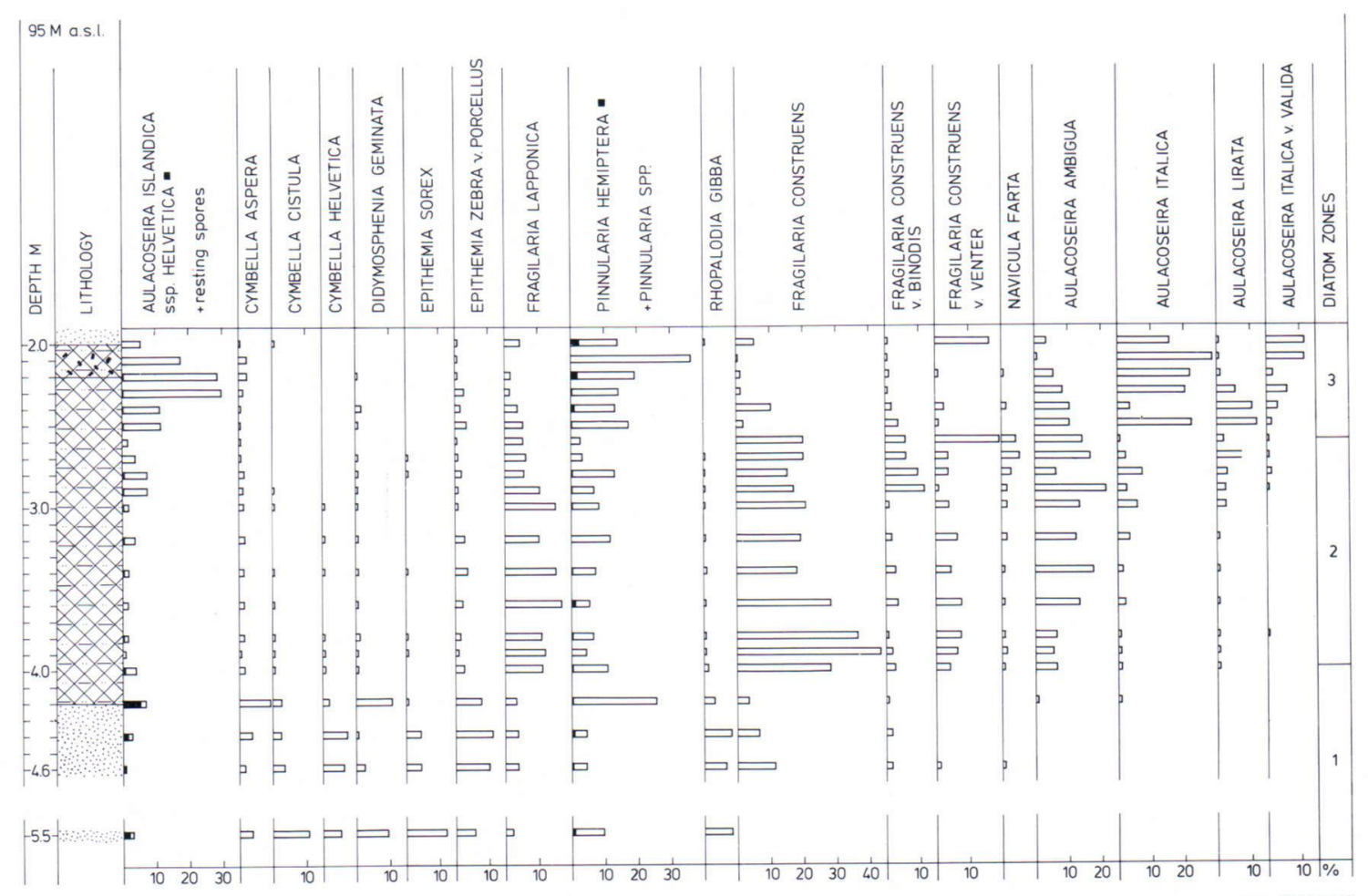

Fig. 10. Taxa accounting for more than $5 \%$ of the total diatom flora at Site A, Marjamurto.

$\mathrm{C}$ were also analysed. Both contained very little pollen, mostly Betula.

The pollen assemblages observed in the gyttja silt and sulphide clay at Site B are indicative of a closed forest in which birch is the dominant tree. These sediments originate either from the beginning or end of an interglacial or from an interstadial.

The redeposited pollen of the channel fill material at Site $\mathrm{C}$ and that of the lump of clay may be derived from the same primary deposit. The pollen spectra of the latter (samples 6-10) reflect mixed birch-pine forests typical of a cool climatic zone, and those of the redeposited pollen (samples 2-5) are entirely comparable with these. These samples may also be said to mark either the beginning or end of an interglacial or an interstadial. The same may also be said of the small lump of clay recovered from the lower edge of the channel, the badly worn pollen from which could be traced to subarctic conditions.

\section{Diatom stratigraphy}

\section{Methods}

The material for diatom analysis was treated by bleaching for 24 hours in $30 \% \mathrm{H}_{2} \mathrm{O}_{2}$ at $50^{\circ}$, followed by repeated suspension and decanting. The mounting medium was Hyrax liquid. At least 500 frustules were identified at each sampling depth. The most common taxa and their frequencies are depicted in separate diagrams (Figs. 10, 12 and 14), and the diatoms are grouped in terms of their $\mathrm{pH}$ requirements and life forms in Figs. 11,13 and 15. 
MARJAMURTO A

Diatoms. $\mathrm{pH}$-spectrum Diatoms, life forms

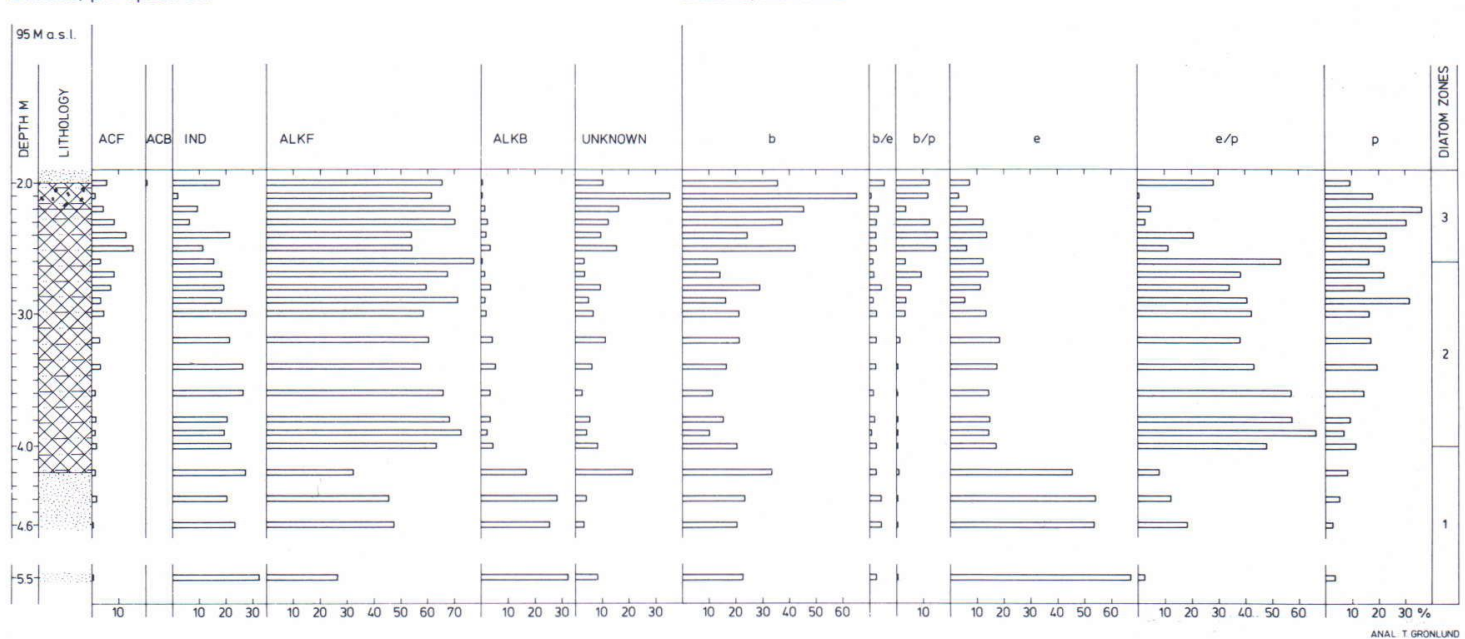

Fig. 11. Composition of the diatom flora at Site A, Marjamurto, on the basis of $\mathrm{pH}$ requirements and life-forms.

Site A

The diagram (Fig. 10) presents details of those diatom taxa encountered in amounts $>5 \%$ of the total flora. The remainder are presented in Table 2. All 182 taxa identified, representing 31 genera, were freshwater species. The profile is divided into three diatom zones.

\section{Diatom zone 1 (depth $5.5-4.0 \mathrm{~m}$ )}

The sediment in this zone is fine sand. The diatom flora present consists of periphytic forms, principally epiphytes, with smaller numbers of benthic and planktonic forms (Fig. 11).

The $\mathrm{pH}$ spectrum for the diatom flora comprises $26-47 \%$ alkaliphilous species, $12-31 \%$ alkalibiontic species, $27-30 \%$ indifferent species and a few percent acidophilous species and specimens with unknown pH requirements (Fig. 11). The last-mentioned category consists mainly of fragments of Pinnularia spp. which could not be identified to species, although the majority would evidently fall into the indifferent group. The alkalibiontic species in this zone are Cymbella leptoceros, Epithemia sorex, E. turgida, E. zebra var. porcellus, E. zebra var. saxonica and Rhopalodia gibba, while the most significant alkaliphilous species are Cocconeis placentula, Cymbella aspera, C. cistula, C. helvetica and Fragilaria construens. Fairly large numbers of the indifferent species Didymosphenia geminata were also present.

One unusual find was Fragilaria triangulata in the sand at a depth of $5.5 \mathrm{~m}$. This is described from Early Pliocene deposits in the Soviet Far East (Sheshukova-Poretskaya and Moisseva 1964) and has been previously reported from presumably in situ Mio-Pliocene diatomite in Finland, at Naruskajärvi and in silt in Värriöjoki (Tynni 1982). It has been also found in the interglacial deposits from Öje, Sweden and interpreted as redeposited or relict (Robertsson 1988). The specimen from Marjamurto is also regarded as reworked.

In terms of the empirical diatom-based $\mathrm{pH}$ equation of Renberg and Hellberg (1982), the $\mathrm{pH}$ of the water upon deposition of the sediments at a level of $4.60 \mathrm{~m}$ can be calculated to have been as high as 8.1.

Diatom zone 2 (depth $4.0-2.60 \mathrm{~m}$ )

The sediment in this zone is gyttja fine silt with a loss-on-ignition of approximately 5\%. The epiphytic diatoms are again in the majority, 11.6 
$-57.9 \%$, but there are also large numbers of purely planktonic species, $11.1-31.8 \%$ (Fig. 11). Alkaliphilous species are dominant (Fig. 11), with Fragilaria construens, $F$. construens var. binodis, $F$. construens var. venter, $F$. brevistriata and $F$. pinnata the major taxa present. The alkalibiontic species are the same ones as in the previous zone, but greatly reduced in numbers. Outstanding indifferent species are $F$. lapponica and $F$. virescens. It is common for a mass occurrence of Fragilaria spp. to be found immediately after isolation of a lake basin, as was obviously the case during Late Weichselian Bölling and Younger Dryas chronozones (Marciniak 1969, 1979, 1981; Robertsson 1973; Haworth 1976; and Miller 1977). Domination by this same genus has also been observed in interglacial or interstadial freshwater deposits, such as at Leveäniemi (Miller 1971), Oulainen (Forsström 1982) and Pilgrimstad (Robertson 1986). Nowadays most Fragilaria species inhabit the littoral zones of lake basins, usually preferring stagnant water. Aulacoseira ambigua, a common planktonic species in eutrophic water, is encountered here in large numbers.

The formula of Renberg and Hellberg (1982) gives a calculated $\mathrm{pH}$ of 7.5 for this zone (depth $3.20 \mathrm{~m}$ ).

\section{Diatom zone 3 (depth $2.60-2.00 \mathrm{~m}$ )}

The sediment type is still gyttja fine sand. Benthic species are now present in large numbers, $24.2-65.6 \%$, and the benthic-epiphytic species, $0.6-5.8 \%$, and benthic-planktonic species, 3.8 $-15.6 \%$, also increase in this zone, while purely planktonic diatoms are similarly numerous, 9.7-36.4\% (Fig. 11).

In terms of $\mathrm{pH}$, the alkaliphilous species continue to be in the majority, $54.0-70.2 \%$ (Fig. 11 ), while the alkalibionts present consist of the species Cymbella tumida, Epithemia zebra var. porcellus, E. zebra var. saxonica and Rhopalodia gibba. The amounts of Fragilaria spp. have declined markedly, and Aulacoseira spp. are now the dominant species. A. ambigua is less prominent, but $A$. islandica and $A$. islandica ssp. hel- vetica are considerably more common. The fact that these species are found almost exclusively in its resting form would suggest that the conditions were really unfavourable for their growth (cf. Aario 1966). A. islandica ssp. helvetica is an eurythermic cold-water planktonic diatom which is encountered in waters ranging from oligotrophic to eutrophic (Mölder and Tynni 1967). Other Aulacoseira taxa present are the alkaliphilous $A$. italica and $A$. italica var. valida and the acidophilous $A$. lirata, which is common at the beginning of the zone, but decreases markedly in the upper part. The Pinnularia species, which are present throughout the profile, become more prolific in this zone, where the principal species are $P$. hemiptera, $P$. maior and $P$. viridis. Many of the Pinnularia specimens are nevertheless fragments and cannot be identified to species.

The $\mathrm{pH}$ at depth $2.20 \mathrm{~m}$, calculated according to Renberg and Hellberg (1982), is 7.3.

The whole profile is characterised by an alkaliphilous diatom flora in which the combined proportion of alkaliphilous and alkalibiontic species varies in the range $50-77 \%$. Some increase in acidophilous species nevertheless occurs in the upper part of the zone, to reach a maximum of $15 \%$, and the $\mathrm{pH}$ values calculated from the formula of Renberg and Hellberg (1982) also show a clear tendency towards greater acidity in this direction. The diatoms thus show the water in the basin was eutrophic, $\mathrm{pH} 7-8$. Sedimentation occurred in the littoral part of the basin, where the water was relatively shallow. The increase in planktonic species in the upper part of the sediment is not regarded as a sign of a rise in water level, as a significant proportion of the planktonic diatoms consist of resting forms of $\mathrm{Au}$ lacoseira islandica and $A$. islandica ssp. helveti$c a$, probably because of the conditions unfavourable for these species. It is also possible, of course, that the sediments may contain some allochthonous material.

\section{Site B}

Diatoms were analysed in two samples, the 
first composed of gyttja silt and the second of sulphide clay. Both contained relatively few diatoms (Table 3), the flora being similar in the two cases. The majority of the taxa are indifferent in terms of $\mathrm{pH}$, although there are also large numbers of alkaliphilous and some alkalibionts.

Table 3. Diatom taxa identified in the samples from Site B at Marjamurto.

\begin{tabular}{|c|c|c|}
\hline Sample number & 1 & 2 \\
\hline $\begin{array}{l}\text { Achnanthes lanceolata v. elliptica Hust. } \\
\text { Amphora ovalis Kütz. }\end{array}$ & 0.2 & 0.2 \\
\hline Aulacoseira ambigua (Grun.) Simonsen & 1.1 & 0.2 \\
\hline » islandica (O. Müll.) Simonsen & 1.3 & 0.4 \\
\hline $\begin{array}{l}\text { 》 islandica ssp. helvetica O. Müll. } \\
\text { 》 islandica ssp. helvetica (Resting }\end{array}$ & 4.9 & 6.8 \\
\hline spores) & 5.3 & 4.1 \\
\hline » italica (Ehr.) Simonsen & 8.2 & 0.9 \\
\hline » lirata (Ehr.) Ross & 1.1 & 0.2 \\
\hline » lirata v. perglabra (Östr.) Ross & 0.3 & \\
\hline $\begin{array}{l}\text { Caloneis bacillum (Grun.) Cleve } \\
\text { " silicula (Ehr.) Cleve }\end{array}$ & 0.2 & $\begin{array}{l}0.6 \\
0.2\end{array}$ \\
\hline $\begin{array}{l}\text { Cocconeis placentula v. euglypta } \\
\text { (Ehr.) Cleve }\end{array}$ & & 0.2 \\
\hline Cyclotella kützingiana Thwaites & 0.5 & 0.9 \\
\hline Cymatopleura elliptica W. Smith & & 0.2 \\
\hline Cymbella aspera (Ehr.) Cleve & 9.1 & 19.4 \\
\hline Didymosphenia geminata (Lyngb.) & & \\
\hline M. Schmidt & 6.7 & 4.3 \\
\hline Diploneis elliptica (Kütz.) Cleve & 2.0 & 2.4 \\
\hline » elliptica v. ladogensis Cleve & 0.2 & 0.6 \\
\hline » finnica (Ehr.) Cleve & 1.1 & 0.4 \\
\hline " ovalis (Hilse) Cleve & 0.2 & 0.6 \\
\hline Epithemia sorex Kütz. & 1.1 & 0.7 \\
\hline » zebra v. porcellus (Kütz.) Grun. & 2.7 & 7.2 \\
\hline » zebra v. saxonica (Kütz.) Grun. & 0.9 & 2.1 \\
\hline Eunotia praerupta Ehr. & 0.2 & 0. \\
\hline $\begin{array}{l}\text { Fragilaria construens (Ehr.) Grun. } \\
\text { » lapponica Grun. }\end{array}$ & $\begin{array}{l}0.2 \\
0.2\end{array}$ & \\
\hline $\begin{array}{l}\text { Frustulia rhomboides v. amphipleuroides } \\
\text { (Grun.) Cleve }\end{array}$ & 0.2 & \\
\hline Melosira arenaria Moore & 2.6 & 0.6 \\
\hline $\begin{array}{l}\text { Navicula pseudoscutiformis Hust. } \\
\text { » radiosa Kütz. }\end{array}$ & $\begin{array}{l}0.2 \\
0.2\end{array}$ & 0.2 \\
\hline Nitzschia denticula Grun. & 0.7 & 0.2 \\
\hline Opephora martyi Herib. & & 0.2 \\
\hline Pinnularia divergens W. Smith & & 0.2 \\
\hline » hemiptera (Kütz.) Cleve & 0.2 & \\
\hline » lata (Bréb.) W. Smith & 0.3 & \\
\hline 》spp. (fragm.) & 45.4 & 44.5 \\
\hline Rhopalodia gibba (Ehr.) O. Müll. & 0.2 & 0.2 \\
\hline Stauroneis acuta W. Smith & 0.2 & \\
\hline » phoenicenteron (Nitzsch) Ehr. & 1.4 & 0.7 \\
\hline Surirella elegans (Ehr.) Bréb. & 0.2 & 0.2 \\
\hline Tetracyclus emarginatus (Ehr.) W.Sm. & 0.3 & \\
\hline " lacustris Ralfs & 0.2 & \\
\hline
\end{tabular}

There are only a few species indicative of acidic water.

The dominant genus is Pinnularia, but most of its frustules are fragmentary, so that identification to species is difficult. The flora includes large numbers of 'clear water diatoms', typical of the Holocene Ancylus Lake and sediments deposited in comparable environments. The following clear water species are encountered in the Site B samples: Melosira arenaria, Aulacoseira islandica, A. islandica ssp. helvetica, Cymatopleura elliptica, Amphora ovalis, Opephora martyi, Diploneis elliptica and Cymbella aspera. The majority of the taxa are epiphytic or benthic in habitat, and the flora as a whole can be interpreted as indicating transparent alkaline or neutral water in a littoral location.

\section{Site C}

Diatom analyses were performed on the 11 samples obtained, the results being depicted in Figure 12, representing samples $1-5$, and Figure 14 , representing samples $6-10$. These diagrams contain all taxa accounting for more than $2 \%$ of the total count. The other taxa and those identified in sample 11 are listed in Table 4 . The diatoms are also grouped according to habitat and $\mathrm{pH}$ requirements (Figs. 13 and 15 ).

MARJAMURTO C1
Diatoms

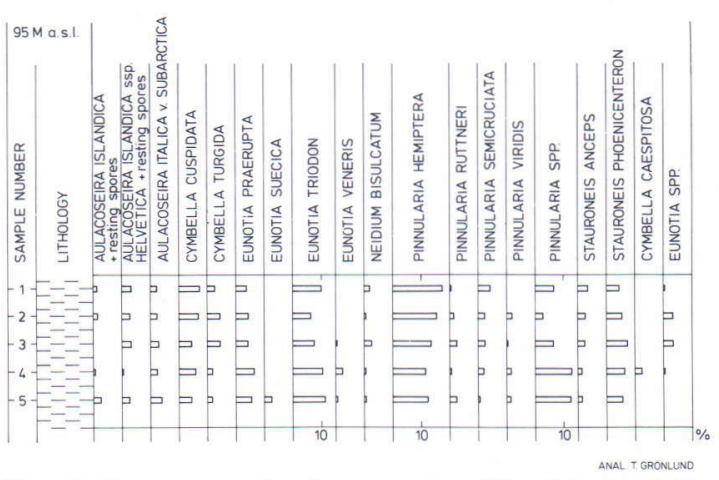

Fig. 12. Taxa accounting for more than $2 \%$ of the total diatom flora in samples $1-5$ (an isolated clay clast) from Site $\mathrm{C}$ at Marjamurto. 
All the samples contain a moderately large number of diatoms, with a flora of the same type throughout. A total of 139 taxa representing 30 genera were identified in samples $1-5$ and 116 taxa representing 25 genera in samples 6-10. Almost a half of the diatoms are acidophilous (Figs. 13 and 15), and there are also many interpreted as indifferent. The principal species present are Eunotia flexuosa, E. lunaris, E. praerupta, E. papilio, Pinnularia hemiptera, $P$. ruttneri and $P$. viridis. The Eunotia species are common in water with a high humus content and low calcium content. E. lunaris and E. praerupta are facultative terrestrial diatoms (Florin 1970), while Pinnularia borealis, Hantzshia amphioxys, Neidium bisulcatum, Navicula mutica and N. mutica var. cohnii are all true euterrestrial species. Other species present in the flora which deserve individual mention are Cymbella cuspidata and Stauroneis phoenicenteron.

One diatom species was also encountered which does not belong to this flora, a specimen of Melosira sulcata, an indicator of saline conditions, in sample 10. This species is frequently found in assemblages interpreted as representing the Eemian Baltic Sea in Finland (cf. Niemelä and Tynni 1979, Eriksson et al. 1980, Grönlund 1988), and has also been identified among the Akanvaara Tertiary diatom flora (Tynni 1982).

In terms of habitat, the majority of the diatoms represent benthic or epiphytic species (Figs. 13 and 15), with only a few planktonic ones, the most prominent being Aulacoseira islandica and

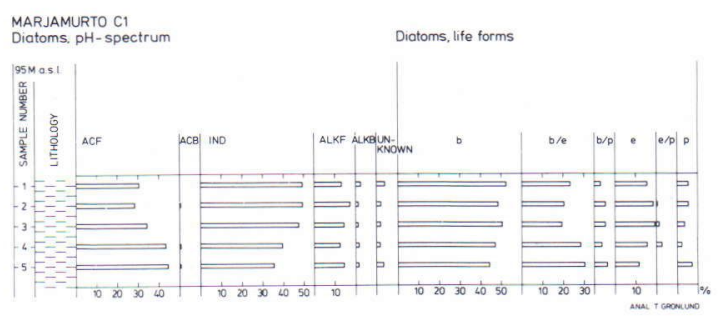

Fig. 13. Composition of the diatom flora in samples $1-5$ from Site $\mathrm{C}$ at Marjamurto, on the basis of $\mathrm{pH}$ requirements and life-forms.

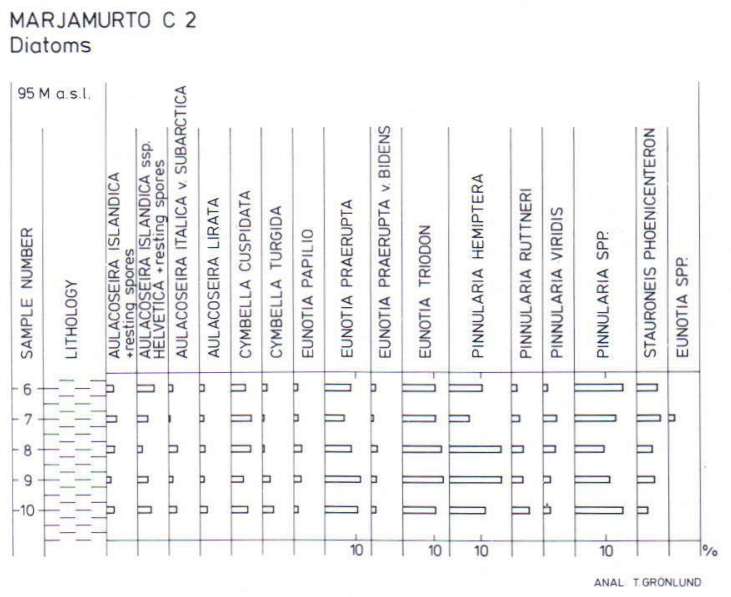

Fig. 14. Taxa accounting for more than $2 \%$ of the total diatom flora in samples 6-10 (an isolated clay clast) from Site $\mathrm{C}$ at Marjamurto.

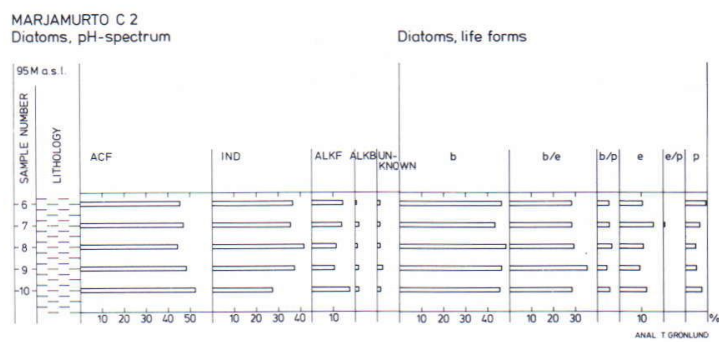

Fig. 15. Composition of the diatom flora in samples 6-10 from Site $\mathrm{C}$ at Marjamurto, on the basis of $\mathrm{pH}$ requirements and life-forms.

A. islandica ssp. helvetica, which were again found mainly in their resting form.

Use of the formula of Renberg and Hellberg (1982) gave a calculated environmental $\mathrm{pH}$ of 6.4 for sample 3 and 6.3 for sample 8 . The redeposited diatom flora of Site $\mathrm{C}$ can thus be interpreted as having been laid originally down in a shallow basin, the water of which was dystrophic oligotrophic.

\section{Comparison of Sites $A, B$ and $C$}

The diatom results obtained from the above three sites at Marjamurto differ so markedly that they cannot be derived from the same phase in 
the same basin. The succession at Site A indicates alkaline water, with some evidence of a transition to less alkaline conditions towards the top of the profile, as is typical of the Holocene development of many lake basins in Finland. The individual samples obtained at Site B, on the other hand, point to similar but more neutral conditions, although the possible involvement of redeposited frustules makes interpretation difficult. Finally, the flora at Site C must, from its position, be regarded as redeposited, although it is internally so coherent that all the material can be assumed to have been derived from the same basin.

\section{Conclusions and correlations}

The pollen stratigraphy of the in situ profile from Site A (Fig. 7) reflects a forest history in which a brief birch-pine phase was followed by a protracted phase of complete domination by pine forest. Numerous deposits have been discovered in Ostrobothnia, although generally fragmentary, which have been dated to the Eemian interglacial Stage (cf. Niemelä and Tynni 1979, Eriksson et al. 1980, Forsström et al. 1987, 1988, Hirvas and Nenonen 1987, Donner 1988, Gibbard et al. 1989) and which have been shown to represent the pre-temperate, early-temperate (climatic optimum), late-temperate and even post-temperate substages. However, none of these has been found to contain a pine zone comparable with that found at Marjamurto.

The Oulainen site, which appears to be located on the same buried esker chain as Marjamurto and is only about $30 \mathrm{~km}$ away, includes an organic deposit overlain by till. This was originally interpreted by Forsström (1982) as of interglacial character, although it was later shown to represent an interstadial interval (Donner 1983; Hyvärinen 1985; Forsström et al. 1987; Donner 1988; Forsström 1988). Thus Donner et al. (1986) refer to this interval as the Oulainen Interstadial and correlate it with the Early Weichselian
Brørup Interstadial, a date that is confirmed in the later publications listed above.

The local pollen assemblage zones recognised in the Marjamurto Site A diagram are virtually identical to the upper part of the birch zone and the pine zone in the Oulainen profile. The thermoluminescence dates from Oulainen of $94 \mathrm{ka}$ and $121 \mathrm{ka}$ for the sand horizons (Jungner 1987), which over- and underlie the gyttja, indicate sedimentation of the organic sediment in substage $5 \mathrm{c}$ of the deep-sea oxygen isotope stratigraphy, i.e. around $105 \mathrm{ka}-93 \mathrm{ka}$ B.P. (Martinson et al. 1987). Mangerud (in press) in fact regards it as probable that the first warm climatic phase following the Eemian Stage, the Brørup Interstadial, can indeed be correlated with substage $5 \mathrm{c}$.

Further buried organic sediments at Vimpeli, about $140 \mathrm{~km}$ south of Marjamurto, were again initially correlated with the Eemian interglacial Stage (Aalto et al. 1983, c.f. also 1989), but these were later likewise reassigned to the same event as the Oulainen deposit, i.e. the Oulainen Interstadial. The three profiles composed of inwashed peat found at Vimpeli include a birch zone, followed by a markedly pine-dominated zone. Therefore the pollen succession is again comparable to that at Oulainen and in the Site A profile at Marjamurto. In all three sites the pollen stratigraphy represents the earlier part of an interstadial succession from birch- to pine-dominated forests in Ostrobothnia.

According to Forsström (1988), the organic material contained in sand and gravel, from the till-covered esker at Ruottisenharju in Pudasjärvi commune (Forsström 1982) may be equated with the Brørup Interstadial, and again the pollen assemblages suggest the contemporary presence of birch and pine in the area. No evidence of spruce, or alder were found. Indeed Forsström (1988) emphasises the close correspondence of these assemblages and those from the Oulainen interstadial sediments. Thus it seems that the Ruottisenharju organic material can be attributed to the same phase as represented at Vimpeli and Marjamurto. 
Organic sediments overlain by till in the Harrinkangas esker (Fig. 1) have been recently investigated by Gibbard et al. (1989). Pollen analysis from the sediments indicates a tree-dominated vegetation with Pinus, Picea and Betula in the lower half of the profile. The pollen flora of this local pollen assemblage zone resembles the pinedominated zones in the sequences from Oulainen, Vimpeli and Marjamurto, site A. In contrast the upper part of the Harrinkangas profile the pollen flora is herb-dominated. On the basis of the diatom assemblage present the sediments accumulated in a freshwater basin. Gibbard et al. conclude therefore that the Harrinkangas esker is of late Saalian age. The organic sediments have been tentatively interpreted as representing the end of an interglacial, possibly the Eemian Stage.

However, there are no other proposed interstadial sediments in Fennoscandia which correspond in pollen composition to the stratigraphy of Site A at Marjamurto. The pollen assemblage typical of the Peräpohjola Interstadial defined by Korpela (1969) in Northern Finland, for example, with which the other interstadial sediments discovered in Lapland have been correlated (Kujansuu 1975; Hirvas et al. 1977; Mäkinen 1979), is entirely dominated by birch, reflecting subarctic conditions.

Research has been carried out at a number of sites known in Norrbotten in the extreme north of Sweden where two organic deposits are separated by a bed of till (Lagerbäck and Robertsson 1988). It has been claimed that these organic deposits represent two interstadials, the older being correlated with the Peräpohjola ('Brørup') Interstadial in Finnish Lapland and the younger tentatively with the Odderade Interstadial. The pollen flora of both indicates tundra and open birch forest vegetation, and similarly other possible interstadial sediments in Northern and Central Sweden accumulated under prevailing arcticsubarctic conditions (cf. Robertsson 1988).

The profile from Oerel in North-West Germany studied by Behre and Lade (1986) represents a continuous record from the Eemian Stage to the Middle Weichselian Substage. During this period, according to the pollen stratigraphy, only two interstadials included forest vegetation: the Brørup and the Odderade events. Thus only these need be considered when attempting to equate the in situ sediment profile from Marjamurto with the regional Quaternary sequence of NW Europe. Although the uncertainty over absolute dates and the lack of any profile in Ostrobothnia where both interstadials occur in vertical succession prevent firm correlation, the thermoluminescence dates available for the Oulainen site (Jungner 1987), and the strong similarities between the pollen sequences at Marjamurto and Vimpeli, suggests that they should equated with the Brørup Interstadial. It can only be said with certainty, however, that the Marjamurto organic deposits represent an Early Weichselian interstadial, either the Brørup or the Odderade. This matter has been discussed by Forsström (1988).

Sediments containing both interstadial and interglacial diatoms have been discovered in Ostrobothnia, representing either the Eemian or the Early Weichselian, most probably the Brørup Interstadial. There have also been several finds of marine clays thought to have been deposited in the Eemian Baltic Sea, the most significant of which are the Evijärvi deposits (Eriksson et al. 1980) and that at Ollala in Haapavesi (Forsström et al. 1987, Grönlund 1988). The Eemian Baltic Sea has been shown to have been more extensive and had a higher salinity than the Holocene Litorina Sea.

Of the till-covered deposits in Ostrobothnia containing freshwater diatoms, those located closest to Marjamurto geographically are at Oulainen (Forsström 1982; Forsström et al. 1987) and Vimpeli (Aalto et al. 1983). Three diatom profiles are available from Oulainen, all of which indicate a similar flora. The longest profile, site $\mathrm{C}$, consists mostly of diatomite and yields a flora indicative of neutral or alkaline water conditions at the base, that grades upward into more acid conditions (Forsström 1982). This flora is broadly similar to that of Site A at Marjamurto. 
The diatoms encountered at Vimpeli represent a relatively small, cool freshwater lake prior to rapid marsh development along the shore.

The reworked diatomite material, described by Aario (1966) from Haapavesi, may perhaps represent the Oulainen Interstadial (Donner et al. 1986). Of particular significance in this diatom flora is the dominant Melosira (Aulacoseira) islandica, M. (A.) islandica ssp. helvetica and their resting spores. However, these species were not encountered in the Oulainen diatomite (Forsström 1982). At Marjamurto these species reach maximum frequencies of c. $30 \%$ in the diatom analyses from Sites A and B. They also include a significant proportion of resting spores.

The Ollala site lies between Oulainen and Marjamurto, but at a higher elevation of $110 \mathrm{~m}$ compared with 70 and $95 \mathrm{~m}$ respectively for the other localities. All three sites represent the earlier part of an interglacial /interstadial. The Ollala diatom flora indicates marine conditions at first, followed by a transition to freshwater. This transition is interpreted as representing the emergence of the site from the sea as a consequence of isostatic land uplift. Since the Oulainen and Marjamurto sites were still submerged beneath the interglacial Baltic Sea at that time, their freshwater sediments cannot be of the same age as those represented at Ollala deposit, which are correlated with the Eemian Stage.

In conclusion, the Marjamurto site is correlative with the Oulainen Interstadial on the basis of its lithostratigraphy and biostratigraphy. It may, in turn, be equivalent to the Brørup Interstadial of continental NW Europe on the basis of thermoluminescence dates from Oulainen and preliminary determinations from Marjamurto (107 $\pm 15 \mathrm{ka}, \mathrm{H}$. Jungner, personal communication, June 1989). These Early Weichselian sites in Ostrobothnia are overlain by a single till complex, as indeed also are the sites correlated with the Eemian Stage (e.g. Nenonen 1986). This suggests that the Weichselian ice spread to the central and southern parts of Finland only once. Thus the till-covered eskers of Ostrobothnia must themselves date from to the late Saalian. 
Table 2. Diatom taxa occurring at Site A at Marjamurto with a frequency of less than $5 \%$.

\begin{tabular}{|c|c|c|c|c|c|c|c|c|c|c|c|c|c|c|c|c|c|c|c|c|c|c|c|}
\hline \multirow{2}{*}{$\begin{array}{l}\text { Diatom zones } \\
\text { Depth m }\end{array}$} & \multicolumn{6}{|c|}{3} & \multirow{2}{*}{$\begin{array}{l}1 \\
1\end{array}$} & \multicolumn{11}{|c|}{2} & \multirow{2}{*}{$\begin{array}{l}1 \\
1\end{array}$} & \multicolumn{4}{|c|}{1} \\
\hline & 2.0 & 2.1 & 2.2 & 2.3 & 2.4 & 2.5 & & 2.6 & 2.7 & 2.8 & 2.9 & 3.0 & 3.2 & 3.4 & 3.6 & 3.8 & 3.9 & 4.0 & & 4.2 & 4.4 & 4.6 & 5.5 \\
\hline & & & & & & & 1 & & & & & & & & & & & & 1 & & & & \\
\hline Achnanthes affinis Grun. & & & & & & & 1 & 0.2 & & & & & & & & & & & 1 & & & & \\
\hline » biasolettiana (Kütz.) Grun. & 0.2 & 0.2 & & & 0.2 & & 1 & 1.8 & 0.8 & & & & & 0.2 & 0.6 & 0.6 & 1.3 & & 1 & & & & \\
\hline " calcar Cleve & & & & & & & 1 & & & & & & & & & & & & 1 & & & 0.2 & \\
\hline » exigua Grun. & & & & & & & 1 & & & & & 0.2 & & & & & & & 1 & & & 0.6 & \\
\hline » exigua v. heterovalvata Krasske & & & & & 0.2 & & 1 & 0.2 & 0.2 & & & & & & & & & & 1 & & & & \\
\hline » flexella (Kütz.) Brun & & & & & & & 1 & & & & & & & & & & & & 1 & & 0.2 & 0.2 & \\
\hline » kryophila Boye & & & & 0.2 & 0.4 & & 1 & 0.2 & & & & & & & & & & & 1 & & & & \\
\hline " lanceolata (Bréb.) Grun. & & & & & 1.6 & & 1 & 0.7 & & & & & & & & & 0.2 & & 1 & & & . & \\
\hline " lanceolata v. elliptica Hust. & 0.2 & & & & 0.4 & & 1 & 2.8 & 2.2 & 1.0 & 0.4 & 1.8 & 2.4 & 1.8 & 1.0 & 1.0 & 1.6 & 1.6 & 1 & 0.2 & 0.2 & 0.4 & \\
\hline » lanceolata v. rostrata (Östr.) & & & & & & & 1 & & & & & & & & & & & & 1 & & & & \\
\hline Hust. & & & & & & & 1 & 0.2 & 0.8 & 0.4 & 0.2 & 0.4 & 0.4 & & & & & & 1 & 0.2 & & & \\
\hline » levanderi Hust. & 0.4 & & 0.4 & & 2.6 & 0.8 & 1 & 2.2 & 1.6 & & & 1.4 & 1.2 & 1.6 & 1.2 & 1.5 & 2.1 & 0.4 & 1 & & 0.2 & 0.4 & \\
\hline » linearis (W. Sm.) Grun. & & & 0.4 & & & & 1 & & & & & & & & & & & & 1 & & 0.2 & 0.2 & \\
\hline " minutissima v. cryptocephala & & & & & & & 1 & & & & & & & & & & & & 1 & & & & \\
\hline Grun. & & & & & & & 1 & & 0.2 & & & & & & & & & & 1 & & & & \\
\hline » obliqua (Greg.) Hust. & 0.6 & & & & 0.4 & 0.2 & 1 & & 0.6 & & & & 0.2 & & & & & 0.2 & 1 & & & & \\
\hline " peragalli Brun \& Herib. & & & & & & & 1 & 0.4 & 0.2 & & & & & & & & & & 1 & & & & \\
\hline » recurvata Hust. & & & & & 0.6 & & I & 0.2 & 0.4 & & & & & & 0.2 & & & & I & & & & \\
\hline " östrupi (Cleve) Hust. & 0.2 & & & & 1.0 & 0.2 & 1 & 0.2 & 1.8 & 0.4 & 0.2 & 0.4 & 1.2 & 1.0 & 1.0 & 0.2 & 0.6 & 1.2 & 1 & & & & \\
\hline " spp. & & & & 0.4 & & & 1 & 0.7 & & & & & & 0.6 & & & & & 1 & & 0.2 & & \\
\hline Amphora ovalis Kütz. & & & 0.4 & & & & 1 & & & & 0.2 & 0.2 & 0.6 & 0.4 & 0.4 & 0.6 & 0.2 & 0.8 & 1 & 1.0 & 1.2 & 0.6 & 1.4 \\
\hline » ovalis v. libyca (Ehr.) Cleve & 1.0 & & & 0.2 & 0.2 & 0.4 & 1 & 0.2 & 0.8 & 0.4 & 0.6 & 0.4 & & & 0.4 & 0.2 & 0.2 & 1.0 & 1 & 1.0 & 2.7 & 2.7 & 1.2 \\
\hline " ovalis v. pediculus Kütz. & & & & & 0.2 & & 1 & & & & 0.2 & & & & & & & & 1 & 0.2 & 0.4 & 0.8 & 0.2 \\
\hline Aulacoseira distans v. alpigena & & & & & & & 1 & & & & & & & & & & & & 1 & & & & \\
\hline (Grun.) Simonsen & & & & & & & I & 0.5 & & & & & & & & & & & 1 & & & & \\
\hline " distans v. tenella (Nygaard) & & & & & & & I & & & & & & & & & & & & 1 & & & & \\
\hline Ross & 0.2 & & 0.4 & 0.2 & & & 1 & & & & & & & & & & & & I & & & & \\
\hline » granulata (Ehr.) Ralfs & & & & & 0.6 & 0.2 & 1 & & 0.4 & 0.2 & 1.2 & & 0.2 & & & & 0.2 & & 1 & & & & \\
\hline » islandica (O. Müll.) Simonsen & & & 0.8 & 0.6 & 0.4 & 0.4 & 1 & & & 0.2 & 0.2 & 1.2 & 0.4 & & & 0.8 & & 1.0 & 1 & 1.0 & 1.0 & 1.0 & 1.4 \\
\hline » islandica (Resting spores) & & & 0.2 & 0.2 & & & 1 & & 0.4 & 0.2 & 0.6 & & & & & & 0.2 & & 1 & & & 0.4 & \\
\hline » italica v. subarctica (O. Müll.) & & & & & & & 1 & & & & & & & & & & & & 1 & & & & \\
\hline Simonsen & & & & 0.2 & 0.4 & 0.4 & 1 & & & 0.6 & 0.2 & & 0.2 & & & & & & 1 & & & & \\
\hline » lirata fo. biseriata (Camburn) & & & & & & & 1 & & & & & & & & & & & & 1 & & & & \\
\hline Haworth & & & & & & & 1 & & 0.6 & & & & & & & & & & 1 & & & & \\
\hline » lirata v. lacustris (Grun.) Ross & & & & & & 0.6 & 1 & & & & & & & & & & & & 1 & & & & \\
\hline » lirata v. perglabra (Östr.) Ross & 0.6 & & & 0.4 & & & 1 & & & 0.4 & 0.4 & & & & & & & & 1 & & & & \\
\hline Caloneis bacillum (Grun.) Meresch. & & & & & & & 1 & & & 0.2 & & 0.2 & & 0.2 & 0.2 & 0.2 & 0.2 & 0.6 & 1 & 0.2 & 1.9 & 0.8 & 0.8 \\
\hline » silicula (Ehr.) Cleve & 0.2 & & 0.4 & & & & 1 & & & & 0.4 & & & & 0.2 & 0.4 & & 1.2 & 1 & 1.2 & 3.3 & 0.2 & 1.6 \\
\hline
\end{tabular}


Cocconeis placentula Ehr.

» placentula v. lineata (Ehr.)

Van Heurck

Cyclotella iris Brun

") kützingiana Thwaites

» kützingiana v. radiosa Fricke

stelligera Cleve \& Grun.

Cymatopleura elliptica W. Smith

» solea (Bréb.) W. Smith

Cymbella angustata (W. Sm.)

\section{Cleve}

» cuspidata Kütz.

") gaeumannii Meist.

" gracilis (Rabenh.) Cleve

" lanceolata (Ehr.) Van Heurck

") leptoceros (Ehr.) Grun.

" microcephala Grun.

» obtusa Greg.

») sinuata Greg.

" tumida (Bréb.) Van Heurck

» turgida (Greg.) Cleve

Diploneis elliptica (Kütz.) Cleve

" finnica (Ehr.) Cleve

) marginestriata Hust.

1) ovalis (Hilse) Cleve

» ovalis v. oblongella (Naeg.)

$$
\text { Cleve }
$$

Epithemia turgida (Ehr.) Kütz.

») turgida v. granulata (Ehr.)

Grun.

») zebra (Ehr.) Kütz.

1) zebra v. saxonica (Kütz.)

Grun.

Eunotia arcus Ehr

" bidentula W. Smith

sexigua (Bréb.) Rabh.

y) flexuosa (Bréb.) Kütz.

") formica Ehr.

") lunaris (Ehr.) Grun.

") parallella Ehr.

》 pectinalis (O. Müll.) Rabh

» pectinalis v. minor (Kütz.)

$$
\text { Rabh. }
$$

» polyglyphis Grun.

") praerupta Ehr.

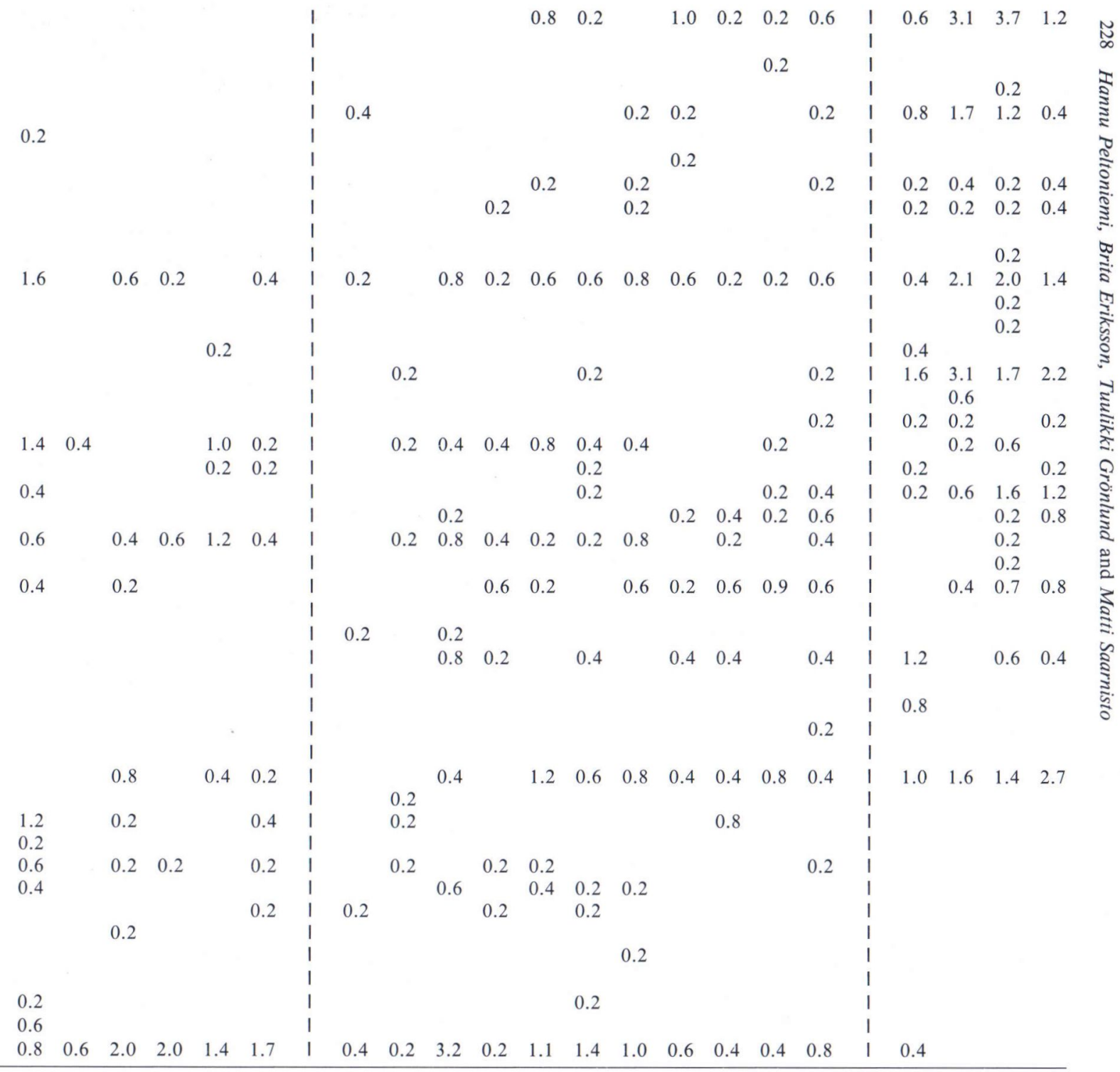


Table 2. Continued.

\begin{tabular}{|c|c|c|c|c|c|c|c|c|c|c|c|c|c|c|c|c|c|c|c|c|c|c|c|}
\hline \multirow{2}{*}{$\begin{array}{l}\text { Diatom zones } \\
\text { Depth m }\end{array}$} & \multicolumn{6}{|c|}{3} & \multirow{2}{*}{$\begin{array}{l}1 \\
1\end{array}$} & \multicolumn{11}{|c|}{2} & \multirow{2}{*}{$\begin{array}{l}1 \\
1\end{array}$} & \multicolumn{4}{|c|}{1} \\
\hline & 2.0 & 2.1 & 2.2 & 2.3 & 2.4 & 2.5 & & 2.6 & 2.7 & 2.8 & 2.9 & 3.0 & 3.2 & 3.4 & 3.6 & 3.8 & 3.9 & 4.0 & & 4.2 & 4.4 & 4.6 & 5.5 \\
\hline & & & & & & & 1 & & & & & & & & & & & & 1 & & & & \\
\hline » praerupta v. bidens Grun. & & & 0.4 & 0.4 & 0.4 & 0.2 & 1 & 0.2 & 0.2 & 0.6 & & 0.6 & & 0.2 & & & 0.2 & & I & & & & \\
\hline » robusta Ralfs & 0.8 & & & & & & 1 & & & & & & & & & & & & 1 & & & & \\
\hline » veneris (Kütz.) O. Müll. & & & & & & & 1 & 0.5 & & & & & & 0.2 & & & & & 1 & & & & \\
\hline Fragilaria brevistriata Grun. & 0.8 & & 1.2 & & 0.6 & & 1 & 0.7 & 0.8 & 0.8 & 0.6 & & 0.4 & & & 0.2 & & & 1 & & 0.2 & & \\
\hline » capucina Desmazières & & & & & & & 1 & & 0.4 & & 0.2 & & & & & & & & 1 & & & & \\
\hline » intermedia Grun. & & & & & & & 1 & & & & & 0.2 & & & & & 0.2 & & 1 & & & & \\
\hline » pinnata Ehr. & 1.0 & & & & & & 1 & 0.5 & 0.8 & & & 0.4 & & 0.2 & & 0.9 & 1.4 & & 1 & 0.6 & & 0.2 & \\
\hline » triangulata Moiss. & & & & & & & 1 & & & & & & & & & & & & 1 & & & & 0.2 \\
\hline ») virescens Ralfs & 0.8 & & & & 1.6 & 0.2 & 1 & 0.7 & 2.2 & & 0.6 & 0.6 & 0.4 & 0.8 & 0.6 & 0.8 & 0.9 & 0.2 & । & & & & \\
\hline Frustulia rhomboides (Ehr.) & & & & & & & 1 & & & & & & & & & & & & 1 & & & & \\
\hline De Toni & & & & & & & 1 & & & & & & & & & & & & 1 & & & 0.2 & \\
\hline » rhomboides v. amphipleuroides & & & & & & & 1 & & & & & & & & & & & & 1 & & & & \\
\hline (Grun.) Cleve & & & & & & & 1 & & & & & & 0.4 & 0.2 & & & & 0.2 & 1 & 0.6 & 1.0 & & 0.4 \\
\hline » vulgaris (Thwaites) De Toni & & & & & & & 1 & & & & & & & & & & & & 1 & & & 0.4 & \\
\hline Gomphonema acuminatum Ehr. & 0.6 & & & & & & 1 & 0.4 & & & & 0.2 & 0.2 & 0.4 & & 0.2 & & & 1 & 0.2 & 0.6 & 1.4 & 0.2 \\
\hline » acuminatum v. coronata & & & & & & & 1 & & & & & & & & & & & & 1 & & & & \\
\hline (Ehr.) W. Sm. & & & & & & & 1 & & & & & & & & & & & & 1 & & 1.2 & 0.6 & 0.8 \\
\hline » augur Ehr. & & & 0.2 & & & & 1 & & & & & & & & & & & & 1 & & & 0.2 & \\
\hline » constrictum Ehr. & 0.4 & & & & & & 1 & & & & & & 0.2 & 0.2 & 0.2 & 0.4 & 0.2 & 0.4 & I & 0.6 & 1.9 & 1.2 & 0.4 \\
\hline » parvulum (Kütz.) Grun. & & & & & & & 1 & & & & & & & & & 0.2 & 0.4 & & 1 & & & & \\
\hline » ventricosum Greg. & & & & & & & 1 & & & & & & & & & & & & 1 & 0.2 & 0.8 & & 0.4 \\
\hline »sp. & & & & & & & 1 & & & & & & & & & & & & I & 0.2 & & & \\
\hline Gyrosigma kützingii (Grun.) Cleve & & & & & & & 1 & & & & & & & & & & & & I & & 0.2 & 0.4 & \\
\hline Hantzschia amphioxys (Ehr.) & & & & & & & 1 & & & & & & & & & & & & 1 & & & & \\
\hline Grun. & & & & & & & 1 & & & 0.2 & & & & 0.2 & & 0.2 & & & 1 & & & & \\
\hline " amphioxys v. vivax (Hantzsch) & & & & & & & 1 & & & & & & & & & & & & 1 & & & & \\
\hline Grun. & & 0.2 & 0.2 & 0.2 & 0.4 & & 1 & 0.2 & & & & 0.2 & & 0.4 & 0.2 & 0.2 & & & I & 0.4 & 0.2 & 0.2 & 0.2 \\
\hline Melosira arenaria Moore & & & 0.4 & 0.6 & 0.8 & 0.2 & 1 & & 0.4 & 0.4 & 0.8 & 0.6 & 0.4 & 0.2 & 0.2 & 0.2 & 0.2 & 0.2 & 1 & 1.0 & 0.4 & 0.4 & 0.4 \\
\hline Navicula americana Ehr. & & & & & 0.2 & & 1 & & & & & & & & 0.2 & & & & 1 & & & & \\
\hline » amphibola Cleve & & & & & & & 1 & & & 0.2 & & & & & & & & & 1 & 0.2 & & & \\
\hline " bacillum Ehr. & & & & & & & I & & & & & & 0.2 & & & & & & 1 & 0.2 & 0.2 & 0.2 & 0.6 \\
\hline " cocconeiformis Greg. & & & & & & & 1 & & & & & 1.6 & 1.2 & 1.2 & 0.4 & & & 1.2 & 1 & 0.2 & & & \\
\hline " costulata Grun. & & & & & & & 1 & 0.4 & & & & & & & & & & & 1 & & & 0.2 & \\
\hline » cuspidata Kütz. & & & & & & & 1 & & & & & & & & & & & & i & & 0.2 & & \\
\hline » exigua Grun. & & & & & & & 1 & & & & & & & & & & & & i & & & & 0.2 \\
\hline " gastrum (Ehr.) Kütz. & 0.4 & 0.2 & & 0.2 & 0.4 & 0.2 & 1 & & 0.4 & 0.4 & 0.8 & 0.4 & 1.2 & 0.6 & 0.2 & & 0.2 & 0.2 & i & 0.2 & & 0.4 & \\
\hline » jentzschii Grun. & 1.0 & & 0.4 & & 1.2 & 0.2 & I & 3.3 & 1.2 & 0.8 & 0.6 & & & & & 2.6 & 1.7 & & i & & & & \\
\hline » lacustris Greg. & & & & & & & 1 & & & & & & & & & & & 0.2 & $i$ & & & & \\
\hline » laterostrata Hust. & & & & & & & 1 & & & & 0.2 & 0.2 & & & 0.2 & & & 0.2 & 1 & & & & \\
\hline " menisculus Schumann & & & & & & & I & & & & & & & & & & & & I & & & & 0.2 \\
\hline
\end{tabular}


» pseudoscutiformis Hust.

" pupula Kütz.

pupula v. rectangularis (Greg.) Grun.

") radiosa Kütz.

" radiosa v. tenella (Bréb. \& Kütz.) Grun

" rhynchocephala Kütz.

s schroeteri Meister

" $\mathrm{sp}$

Neidium affine (Ehr.) Pfitz.

» bisulcatum (Lager.) Cleve

» hitchcockii (Ehr.) Cleve

iridis (Ehr.) Cleve

" iridis fo. vernalis Reich.

") ladogensis (Cleve) Foged

Nitzschia angustata (W. Sm.) Grun.

") angustata v. acuta Grun.

) denticula Grun.

Opephora martyi Herib.

Pinnularia borealis Ehr.

» brevicostata Cleve

» divergens W. Smith

y) gentilis (Donkin) Cleve

》) gibba Ehr.

») gibba fo. subundulata Mayer, Hust.

》 hemiptera (Kütz.) Cleve

》) lata (Bréb.) W. Smith

"macilenta (Ehr.) Cleve

maior (Kütz.) Rabh.

" mesolepta (Ehr.) W. Sm.

nodosa (Ehr.) W. Sm.

semicruciata A. Cleve

" streptoraphe Cleve

subsolaris (Grun.) Cleve

viridis (Nitzsch) Ehr.

" viridis v. sudetica (Hilse) Hust.

Stauroneis acuta W. Smith

" anceps Ehr.

phoenicenteron (Nitzsch) Ehr.

») producta Grun

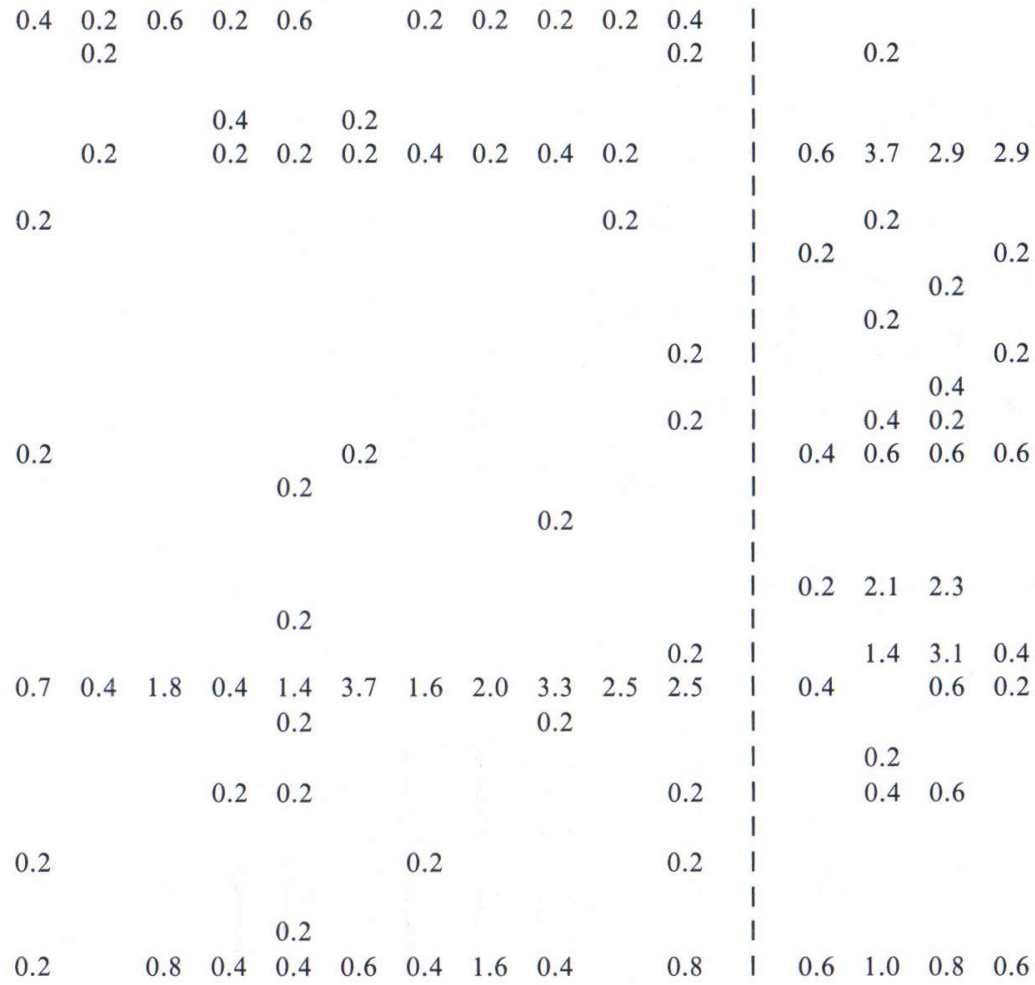


Table 2. Continued.

\begin{tabular}{|c|c|c|c|c|c|c|c|c|c|c|c|c|c|c|c|c|c|c|c|c|c|c|c|}
\hline \multirow{2}{*}{$\begin{array}{l}\text { Diatom zones } \\
\text { Depth m }\end{array}$} & \multicolumn{6}{|c|}{3} & \multirow{2}{*}{$\begin{array}{l}1 \\
1\end{array}$} & \multicolumn{11}{|c|}{2} & \multirow{2}{*}{$\begin{array}{l}1 \\
1\end{array}$} & \multicolumn{4}{|c|}{1} \\
\hline & 2.0 & 2.1 & 2.2 & 2.3 & 2.4 & 2.5 & & 2.6 & 2.7 & 2.8 & 2.9 & 3.0 & 3.2 & 3.4 & 3.6 & 3.8 & 3.9 & 4.0 & & 4.2 & 4.4 & 4.6 & 5.5 \\
\hline & & & & & & & 1 & & & & & & & & & & & & 1 & & & & \\
\hline Stephanodiscus astraea (Ehr.) & & & & & & & 1 & & & & & & & & & & & & 1 & & & & \\
\hline Grun. & & & & & & & 1 & & & & & & & & & & & & 1 & & 0.4 & & \\
\hline Surirella biseriata Bréb. & & & & & & & 1 & & & & & & & & & & & & 1 & & & & 0.4 \\
\hline » capronii Bréb. & & & & & & & 1 & & & & & & & & 0.2 & & & & 1 & & & & \\
\hline » elegans (Ehr.) Bréb. & & & & & & & 1 & & & 0.2 & & & & 0.2 & & & & 0.2 & 1 & 0.6 & 0.4 & 0.2 & 0.8 \\
\hline » robusta v. splendida (Ehr.) & & & & & & & 1 & & & & & & & & & & & & 1 & & & & \\
\hline Van Heurck & & & & & & & 1 & & & & & & & & & & & & 1 & & & 0.2 & \\
\hline » tenera Greg. & & & & & & & 1 & & & & & & & & & & & & । & 0.2 & & & \\
\hline Synedra capitata Ehr. & & & & & & & 1 & & & & & & & & & & & & 1 & 0.2 & & 0.2 & \\
\hline » paracitica (W. Sm.) Hust. & 0.2 & & 0.4 & & 1.2 & & I & 0.2 & 2.0 & & & 0.2 & 0.8 & 0.6 & 0.8 & & 0.6 & 0.8 & 1 & & & & \\
\hline ») paracitica v. subconstricta & & & & & & & I & & & & & & & & & & & & 1 & & & & \\
\hline (Grun.) Hust. & & & & & & & 1 & 0.4 & 0.4 & & & 0.2 & & 0.2 & & 0.2 & 0.8 & 0.2 & 1 & & & & \\
\hline » ulna (Nitzsch) Ehr. & & & & & & & I & & & & & 0.2 & 0.2 & 0.2 & & & & 0.2 & 1 & & 0.2 & 0.2 & 0.2 \\
\hline Tabellaria fenestrata (Lygb.) & & & & & & & 1 & & & & & & & & & & & & 1 & & & & \\
\hline Kütz. & & & & & 0.2 & & I & 0.2 & & 0.2 & & & 0.2 & 0.2 & & & 0.2 & & 1 & & & & \\
\hline 》 flocculosa (Roth) Kütz. & & & & & & & 1 & 0.2 & 0.2 & & & 0.4 & 0.2 & 0.6 & 0.4 & & & & 1 & & 0.4 & 0.2 & \\
\hline Tetracyclus emarginatus (Ehr.) & & & & & & & 1 & & & & & & & & & & & & 1 & & & & \\
\hline W. Sm. & & & & & 0.4 & 0.4 & 1 & & & 0.2 & 0.2 & & & 0.8 & 0.2 & 0.4 & & 0.4 & I & 0.2 & & & \\
\hline ") lacustris Ralfs & 0.2 & & & & & 0.2 & 1 & & & & & & & & & & 0.2 & & 1 & & 0.2 & & \\
\hline
\end{tabular}


Table 4. Diatom taxa occurring at Site C at Marjamurto, with a frequency of less than $2 \%$.

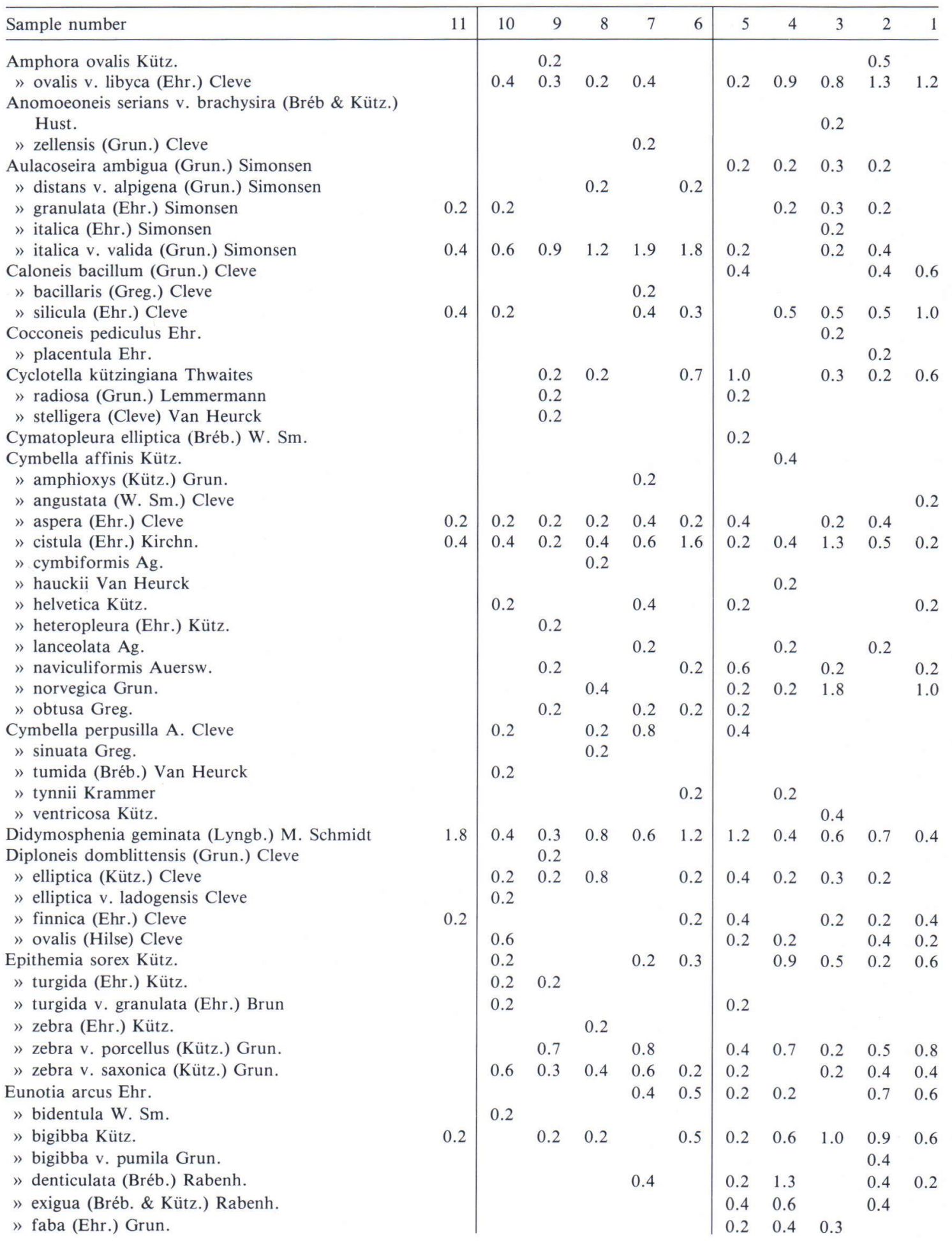


Table 4. Continued.

\begin{tabular}{|c|c|c|c|c|c|c|c|c|c|c|c|}
\hline Sample number & 11 & 10 & 9 & 8 & 7 & 6 & 5 & 4 & 3 & 2 & 1 \\
\hline » fallax A. Cleve & & & & & & 0.3 & & & 0.2 & & 0.4 \\
\hline » flexuosa Kütz. & & 0.4 & 0.2 & & 0.6 & 0.5 & 0.6 & 0.4 & 0.8 & 0.7 & 0.2 \\
\hline » formica Ehr. & 0.2 & 0.2 & 0.2 & 0.2 & 0.2 & 0.2 & 0.4 & & & & \\
\hline » gracilis W. Sm. & & & 0.3 & 0.2 & 0.6 & & & & & & \\
\hline » lapponica Grun. & & 0.2 & 0.5 & 0.6 & 1.2 & & 0.8 & & & & \\
\hline ") lunaris (Ehr.) Grun. & & 0.4 & 0.2 & 0.4 & & 0.9 & 0.4 & 1.1 & 0.8 & 0.6 & 1.0 \\
\hline » meisteri Hust. & & & & & & & & 0.2 & & & \\
\hline » monodon Ehr. & 1.2 & 0.2 & 0.7 & & 0.4 & 0.3 & 0.6 & 0.4 & & 0.2 & 0.2 \\
\hline » parallela Ehr. & & & 0.2 & 0.4 & 1.0 & 0.9 & 0.4 & 0.2 & 0.5 & 1.1 & 1.6 \\
\hline » pectinalis (O. Müll.) Rabenh. & & & & & & & & 0.2 & & & \\
\hline » pectinalis v. minor (Kütz.) Rabenh. & & & & & 0.4 & & 0.4 & 0.6 & & & 0.2 \\
\hline »polyglyphis Grun. & 0.2 & 1.0 & 1.0 & & 0.6 & 0.7 & 1.0 & 0.9 & 0.5 & 0.9 & 0.8 \\
\hline » praerupta v. inflata Grun. & & & & & & & 1.2 & & & & \\
\hline » robusta Ralfs & & 0.2 & 0.5 & 0.2 & 0.6 & & 0.8 & 0.4 & 0.2 & 0.2 & \\
\hline » tenella (Grun.) Cleve & & 0.2 & 0.2 & & 0.8 & 0.2 & 0.2 & 0.2 & 1.6 & 0.2 & 1.6 \\
\hline » valida Hust. & & & & & & & 0.2 & & & & \\
\hline Fragilaria brevistriata Grun. & & & & & & & & 0.4 & & & \\
\hline » constricta Ehr. & & & & & & & & 0.4 & & & \\
\hline » construens v. venter (Ehr.) Grun. & & & & & & & & 0.4 & & & \\
\hline Frustulia rhomboides v. amphipleuroides (Grun.) & & & & & & & & & & & \\
\hline De Toni & & & & & & & & & & & 0.2 \\
\hline Comphonema acuminatum Ehr. & & & 0.3 & 0.4 & 0.2 & 0.2 & 0.4 & 0.2 & 0.6 & 0.2 & \\
\hline » acuminatum v. coronata (Ehr.) W. Sm. & & 0.2 & & & 0.2 & & 0.2 & & & & \\
\hline » angustatum v. undulata Grun. & & & & & & & & & 0.3 & & \\
\hline » constrictum Ehr. & & 0.4 & & & & 0.2 & 0.4 & 0.2 & 0.3 & 0.4 & 0.2 \\
\hline » parvulum Kütz. & & & & & & & & 0.2 & & 0.2 & \\
\hline » spp. Ehr. & & 0.2 & & & 0.6 & & & 0.4 & & & \\
\hline Hantzschia amphioxys (Ehr.) Grun. & 0.8 & 0.4 & 1.0 & 1.8 & 0.6 & 1.1 & 0.4 & 1.5 & 1.3 & 1.5 & 1.4 \\
\hline » amphioxys v. vivax (Hantzsch) Grun. & & 0.6 & & & & & 0.2 & & & & \\
\hline Melosira arenaria Moore & 0.4 & 0.2 & 0.2 & 0.4 & 0.8 & 0.2 & 0.4 & 0.2 & 0.5 & 0.4 & 0.4 \\
\hline » sulcata (Ehr.) Kütz. & & & & & & & & & & 0.2 & \\
\hline Navicula americana Ehr. & & & & & & & & & & 0.2 & 0.2 \\
\hline » bacillum Ehr. & & & & & & & & & & & 0.4 \\
\hline » elegans W. Sm. & 0.2 & & & & 0.2 & & & & & & \\
\hline » gastrum (Ehr.) Kütz. & & & & & 0.2 & & & & & & \\
\hline ") mutica Kütz. & & & 0.2 & & 0.2 & & & & & & 0.2 \\
\hline » mutica v. cohnii (Hilse) Grun. & & 0.2 & & & & & 0.2 & & 0.2 & 0.2 & \\
\hline » pseudoscutiformis Hust. & & & & & & & & 0.2 & & & \\
\hline » pupula Kütz. & & & & & & & & 0.2 & 0.2 & & \\
\hline » pupula v. rectangularis (Greg.) Grun. & & & & & & & & & & 0.2 & 0.6 \\
\hline » radiosa Kütz. & 0.2 & & & 0.2 & 0.2 & 0.3 & & & & 0.2 & 0.2 \\
\hline » scutiformis Grun. & & & & & 0.2 & & & & & & \\
\hline Neidium affine v. longiceps (Greg.) Cleve & & & & & & & & 0.2 & & & \\
\hline » ampliatum (Ehr.) Gramm. & & & & & & & 0.2 & & & & \\
\hline » hitchcockii Ehr. & & & & & & & & 0.2 & & 0.5 & 0.2 \\
\hline » iridis (Ehr.) Cleve & & & 0.2 & 0.2 & 0.8 & 0.2 & & & 1.0 & 0.9 & 0.4 \\
\hline " iridis fo. vernalis Reichelt & & & & & & 0.2 & 0.4 & 0.4 & 0.3 & 0.2 & 0.2 \\
\hline Nitzschia denticula Grun. & & & & & & 0.2 & & & & & 0.2 \\
\hline Opephora martyi Hérib. & & & & 0.2 & & & & & 0.2 & & \\
\hline Pinnularia acrosphaeria Bréb. & 0.2 & & & & & & & & & & \\
\hline » borealis Ehr. & 1.6 & 1.4 & 1.2 & & 1.4 & 1.1 & 0.2 & 1.1 & 1.4 & 1.3 & 0.8 \\
\hline » brevicostata Cleve & & & & 1.0 & 0.4 & 0.3 & 0.4 & 1.3 & 0.4 & 1.4 & 0.2 \\
\hline » cardinalis (Ehr.) W. Sm. & & & & 0.6 & & & & & & & \\
\hline " divergens W. Sm. & 0.2 & & 0.9 & & 0.4 & 0.3 & 0.2 & 0.6 & 0.6 & 0.5 & 0.2 \\
\hline » esox Ehr. & & & & & & & & 0.2 & & & 0.2 \\
\hline " gibba Ehr. & 0.2 & & & 0.2 & & 0.7 & 0.2 & & 1.3 & 0.7 & 0.8 \\
\hline
\end{tabular}


Table 4. Continued.

\begin{tabular}{|c|c|c|c|c|c|c|c|c|c|c|c|}
\hline Sample number & 11 & 10 & 9 & 8 & 7 & 6 & 5 & 4 & 3 & 2 & 1 \\
\hline $\begin{array}{l}\text { » gibba fo. linearis Hust. } \\
\text { " interrupta W. Sm. } \\
\text { " karelica Cleve }\end{array}$ & & & & & & & & & 0.2 & 0.2 & $\begin{array}{l}0.4 \\
0.2\end{array}$ \\
\hline $\begin{array}{l}\text { " lata (Bréb.) W. Sm. } \\
\text { " maior (Kütz.) W. Sm. }\end{array}$ & 1.6 & 1.2 & 0.9 & 1.2 & 1.6 & 1.6 & $\begin{array}{l}1.0 \\
0.4\end{array}$ & 0.2 & 0.5 & 0.4 & 0.4 \\
\hline » mesolepta (Ehr.) W. Sm. & & & & 0.4 & 0.6 & & & 0.8 & 0.8 & 1.4 & 1.6 \\
\hline $\begin{array}{l}\text { » microstauron (Ehr.) Cleve } \\
\text { » nobilis Ehr. }\end{array}$ & & 0.4 & 0.2 & & 0.6 & 0.2 & 0.2 & 0.4 & 1.1 & 0.9 & \\
\hline $\begin{array}{l}\text { " nodosa (Ehr.) W. Sm. } \\
\text { " platycephala (Ehr.) Cleve }\end{array}$ & 0.2 & 0.2 & 0.3 & 0.6 & 0.2 & & & 1.3 & 1.0 & 2.0 & 1.0 \\
\hline $\begin{array}{l}\text { "stomatophora Mayer } \\
\text { "streptoraphe Cleve }\end{array}$ & & & & & & & 0.2 & & 0.2 & 0.2 & \\
\hline " viridis v. fallax Cleve & 1.2 & & & & 0.4 & 0.2 & & & & & \\
\hline » viridis v. sudetica (Hilse) Hust. & 0.8 & & 0.5 & 0.2 & & 0.3 & 0.2 & & 0.2 & 0.2 & \\
\hline Rhopalodia gibba (Ehr.) O. Müll. & & & & 0.4 & 0.2 & 0.2 & 0.4 & 0.2 & 0.2 & & 0.6 \\
\hline $\begin{array}{l}\text { Stauroneis acuta W. Sm. } \\
\text { " dilatata Ehr. } \\
\text { " smithii Grun. }\end{array}$ & & & & & & 0.2 & & 0.4 & & & 0.2 \\
\hline $\begin{array}{l}\text { Stephanodiscus astraea (Ehr.) Grun. } \\
\text { »sp. }\end{array}$ & 0.2 & 0.4 & 0.2 & & 0.2 & $\begin{array}{l}0.3 \\
0.2\end{array}$ & 0.4 & & & 0.4 & $\begin{array}{l}0.2 \\
0.2\end{array}$ \\
\hline Stephanopyxis sp. fragm. Ehr. & & & & & & & 0.2 & & & & \\
\hline Surirella elegans Ehr. & & & & 0.2 & & 0.2 & & & & 0.2 & \\
\hline $\begin{array}{l}\text { Tabellaria fenestrata (Lyngb.) Kütz. } \\
\text { » flocculosa (Roth) Kütz. }\end{array}$ & & & & & 0.4 & & & $\begin{array}{l}0.4 \\
1.7\end{array}$ & 1.1 & 0.5 & \\
\hline $\begin{array}{l}\text { Tetracyclus emarginatus (Ehr.) W. Sm. } \\
\text { » lacustris Ralfs } \\
\text { » lacustris v. capitata Hust. }\end{array}$ & 1.0 & 0.6 & & 0.2 & & 0.5 & 0.8 & & 0.2 & 0.2 & $\begin{array}{l}0.6 \\
0.2\end{array}$ \\
\hline
\end{tabular}

\section{References}

Aalto, M.; Donner, J.; Niemelä, J. \& Tynni, R., 1983. An eroded interglacial deposit at Vimpeli, South Bothnia, Finland. Geol. Surv. Finland, Bull. 324. 42 pp.

-; Donner, J.; Hirvas, H. \& Niemelä, J., 1989. An interglacial beawer dam deposit at Vimpeli, Ostrobothnia, Finland. Geol. Surv. Finland, Bull. 348. 34 pp.

Aario, R., 1966. Kieselgur in fluvioglazialen Ablagerungen in Haapajärvi in Ostbottnien. C. R. Soc. Géol. Finlande XXXVIII, 3-30.

Behre, K.-E. \& Lade, U., 1986. Eine folge von Eem und 4 Weichsel-Interstadialen in Oerel/Niedersachsen und ihr Vegetationsablauf. Eiszeitalt. u. Gegenw. 36, 11-36.

Donner, J., 1983. The indentification of Eemian interglacial and Weichselian interstadial deposits in Finland. Ann. Acad. Sci. Fennicae A III, 136. 38 pp.

-, 1988. The Eemian site of Norinkylä compared with other interglacial and interstadial sites in Ostrobothnia, Western Finland. Ann. Acad. Sci. Fennicae A III, 149. 31 pp.

-; Korpela, K. \& Tynni, R., 1986. Veiksel-jääkauden alajaotus Suomessa. Terra Vol. 98, 3, 240-247.
Eriksson, B.; Grönlund, T. \& Kujansuu, R., 1980. Interglasiaalikerrostuma Evijärvellä, Pohjanmaalla. Summary: An interglacial deposit at Evijärvi in the Pohjanmaa region, Finland. Geologi 32, 65-71.

Forsström, L., 1982. The Oulainen interglacial in Ostrobothnia, western Finland. Acta Univ. Ouluensis A, 136. Geol. 4. $123 \mathrm{pp}$.

-, 1988. The northern limit of pine forest in Finland during the Weichselian interstadials. Ann. Acad. Sci. Fennicae A III, 147. 24 pp.

-; Eronen, M. \& Grönlund, T., 1987. On marine phases and shore levels of the Eemian interglacial and Weichselian interstadials on the west of Ostrobothnia, Finland. Geol. Surv. Finland, Spec. Paper 2, 37-42.

-; Aalto, M.; Eronen, M. \& Grönlund, T., 1988. Stratigraphic evidence for Eemian crustal movements and relative sea-level changes in Eastern Fennoskandia. Palaeogeography, Palaeoclimatol., Palaeoecol., 68, 317-335.

Florin, M.-B., 1970. Late-glacial Diatoms of Kirchner Marsh southeastern Minnesota. Nova Hedwigia, 31, 667-756.

Gibbard, P.; Forman, S.; Salomaa, R.; Alhonen, P.; Jungner, H.; Peglar, S.; Suksi, J. \& Vuorinen, A., 1989. Pleisto- 
cene stratigraphy at Harrinkangas, Kauhajoki, Western Finland. Ann. Acad. Sci. Fenn. A III, 150. 36 pp.

Grönlund, T., 1988. The diatom flora of the Eemian deposit at Haapavesi, western Finland. Geol. Surv. Finl., Rep. of invest. $79.14 \mathrm{pp}$.

Haworth, E., 1976. Two Late-glacial (Late Devensian) diatom assemblage profiles from northern Scotland. New Phytol. 77, 227-256.

Hirvas, H.; Alfthan, A.; Pulkkinen, E.; Puranen, R. \& Tynni, $R ., 1977$. Raportti malminetsintää palvelevasta maaperätutkimuksesta Pohjois-Suomessa vuosina 1972-1976. Summry: A report of glacial drift investigations for oreprospecting in northern Finland 1972-1976. Geol. Surv. Finl. Rep. of Invest. 19. 54 pp.

-, \& Nenonen, K., 1987. The till stratigraphy of Finland. Geol. Surv. Finl., Spec. Pap. 3, 49-63.

Hyvärinen, H., 1985. Weichselian and Eemian correlations in Finland: a discussion. Boreas 14, 262-263.

Iisalo, E., 1973. Soravarojen arviointi TVL:n Keski-Pohjanmaan piirissä. Geologisen tutkimuslaitoksen tutkimusseloste. $116 \mathrm{pp}$.

-; Kurkinen, I. \& Niemelä, J., 1974. Moreenipeitteisiä harjuja Pohjanmaalla. Summary: Till-covered eskers in Ostrobothnia. Geologi 26, 51-52.

Jungner, H., 1987. Thermoluminescence dating of sediments from Oulainen and Vimpeli, Ostrobothnia, Finland. Boreas 16, 231-235.

Korpela, K., 1969. Die Weichsel-Eiszeit und ihr Interstadial in Peräpohjola (nördliches Nordfinnland) im Licht von submoränen sedimenten. Ánn. Acad. Sci. Fennicae A III, 99. $108 \mathrm{pp}$.

Kujansuu, R., 1975. Marrasjärven interstadiaalinen harju Keski-Lapissa. Summary: Interstadial esker at Marrasjärvi, Finnish Lapland. Geologi 27(4), 45-50.

Lagerbäck, R. \& Robertsson, A.-M., 1988. Kettle holes stratigraphical archives for Weichselian geology and palaeoenvironment in northernmost Sweden. Boreas 17, 439-468.

Mäkinen, K., 1979. Interstadiaalinen turvekerrostuma Tervolan Kauvonkankaalla. Summary: An interstadial peat layer at Kauvonkangas, Finnish Lapland. Geologi 31:5, $82-87$.

Mangerud, $J$., in press. The Scandinavian ice-sheet through the last ingerglacial/glacial cycle. Paläoklimat. 1.

Marciniak, B., 1969. Die ersten Ergebnisse der Diatomeenanalyse der spätglazialen Sedimente des Mikolajki-Sees (NO Polen) Mitt. Int. Ver. Limnol. 17, 344-350.

-, 1979. Dominant Diatoms from Late Glacial and Holocene Lacustrine Sediments in Northern Poland. Nova Hedwigia, 64, 411-426.

-, 1981. Late-Glacial diatom phases at Niechorze in western Pomerania, Acta Geol. Polonica 31, 127-137.

Martinson, D.G.; Pisias, N.G.; Hays, J.D.; Imbrie, J.;
Moore, Jr. T.C. \& Shackleton, N.J., 1987. Age dating and the orbital theory of the ice ages: development of a high-resolution $\mathrm{O}$ to 300,000-year chronostratigraphy. Quat. Res. 27. 29 pp.

Miller, U., 1971. Diatom floras in the sediments at Leveäniemi. Sveriges Geol. Unders. C 658, 104-163.

-, 1977. Pleistocene deposits of the Alnarp Valley, southern Sweden. - Microfossils and their stratigraphical aplication. Univ. Lund, Dept. Quat. Geol., Thesis 4. 125 pp.

Mölder, K. \& Tynni, R., 1967. Über Finnlands rezente und subfossile Diatomeen I. C. R. Soc. Géol. Finlande. No XXXIX, 119-217.

Nenonen, K., 1986. Orgaanisen aineksen merkitys moreenistratigrafiassa. Geologi 38, 41-44.

Niemelä. J. (ed.), 1979. Suomen sora- ja hiekkavarojen arviointiprojekti 1971 - 78. Summary: The gravel and sand resources of Finland; an inventory project 1971-78. Geol. Surv. Finland, Rep. Invest. 42.119 pp.

-, \& Tynni, R., 1979. Interglacial and interstadial sediments in the Pohjanmaa region, Finland. Geol. Surv. Finland, Bull. 302.48 pp.

Punkari, M., 1979. Skandinavian jäätikön deglasiaatiovaiheen kielekevirrat Etelä-Suomessa. Summary: The ice lobes of the Scandinavian ice sheet during the deglaciation in South Finland. Geologi 31, 22-28.

Renberg, I. \& Hellberg, T., 1982. The pH history of lakes in southwestern Sweden, as calculated from the subfossil diatom flora of the sediments. Ambio 11, 30-33.

Robertsson, A.-M., 1973. Late-glacial and Pre-boreal pollen and diatom diagrams from Skurup, southern Scania. Sveriges Geol. Unders. C 679. 75 pp.

-, 1986. The diatom flora of the till-covered sediments at Pilgrimstad, Jämtland - In Nordic Late Quaternary Biology and Ecology (Ed. L.-K. Königsson), Striae, Vol. 24, 213-220.

-, 1988. Biostratigraphical reinvestigations of the till-covered sediments at Pilgrimstad and Öje, central Sweden. University of Stockholm, Dept. Quat. Res., Rep. 10, papers $1-5$.

Salli, I., 1958. Kallioperäkartta - Prequaternary rocks. Lehti - Sheet 2434, Vihanti. Geological map of Finland, 1: 100 000. Geol. Surv. Finl., Espoo.

Shesukova-Poretskaja, V.S. \& Moisseva, A.I., 1964. Diatomeae Aquae dulcis novae et curiosae e neogeno Sibirae occidentalis et orientalis extremi. Nov. Syst. Mizschiku rast. Akad. Nauk USSR Bot. inst. im V.L. Komarova, 92-103.

Tynni, $R$., 1982. The reflection of geological evolution in Tertiary and interglacial diatoms and silicoflagellates in Finnish Lapland. Geol. Surv. Finl., Bull. 320. 40 pp.

Received September 1, 1989

Revision accepted November 7, 1989 


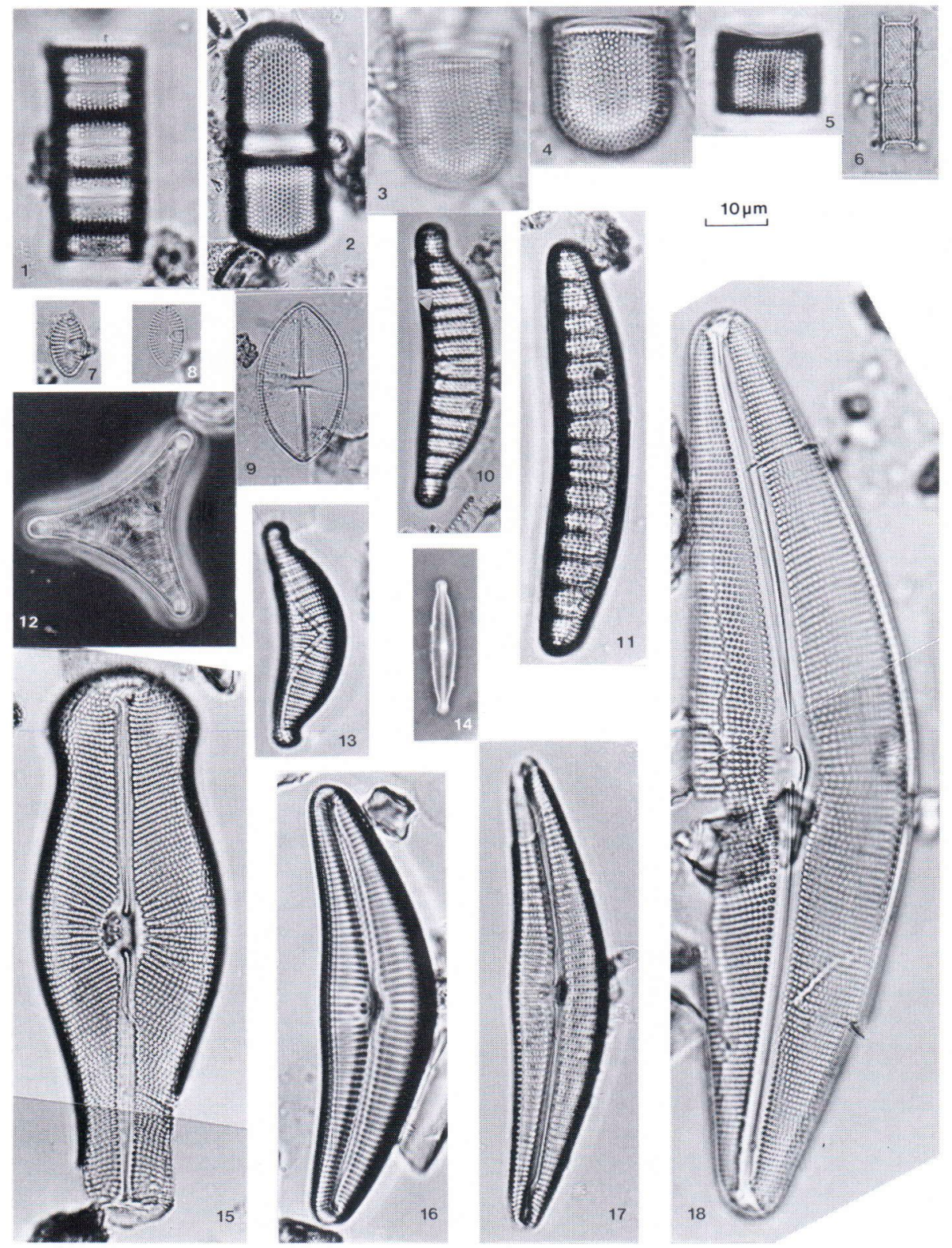

Plate I. Diatoms from Marjamurto Site A: 1. Aulacoseira lirata, 2. Aulacoseira islandica, resting spore, 3. Aulacoseira islandica ssp. helvetica, resting spore, 4. Aulacoseira islandica, resting spore, 5. Aulacoseira islandica, 6. Aulacoseira ambigua, 7. Achnanthes lanceolata var. elliptica, 8. Achnanthes lanceolata var. elliptica, 9. Achnanthes obligua, 10. Epithemia zobra var. porcellus, 11. Epithemia zebra, 12. Fragilaria triangulata, 13. Epithemia sorex, 14. Cymbella microcephala, 15. Didymosphenia geminata, 16. Cymbella cistula, 17. Cymbella helvetica and 18. Cymbella aspera. 

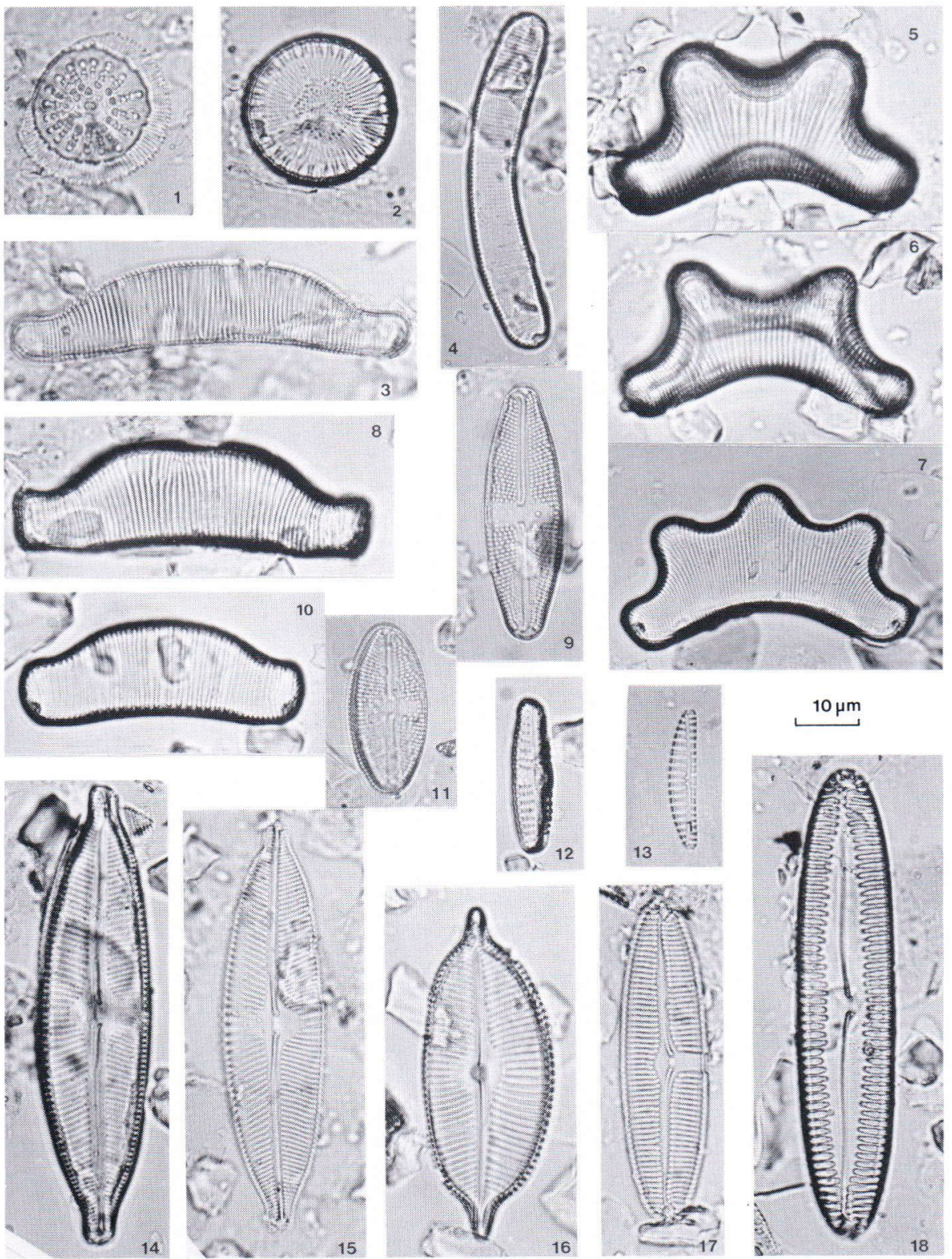

Plate II. Diatoms from Marjamurto Site C: 1. Cyclotella sp., 2. Cyclotella radiosa, 3. Eunotia praerupta var. inflata, 4. Eunotia parallela, 5. Eunotia papilio, 6. Eunotia suecica, 7. Eunotia triodon, 8. Eunotia praerupta, 9. Navicula mutica var. cohnii, 10. Eunotia praerupta, 11. Navicula mutica var. cohnii, 12. Cymbella sinuata, 13. Cymbella perpusilla, 14. Cymbella tynnii, 15. Cymbella tynnii, 16. Cymbella cuspidata, 17. Pinnularia semicruciata and 18. Pinnularia hemiptera. 